\title{
POLLUTION CONTROL IN A TRANSITION ECONOMY: DO FIRMS FACE ECONOMIES AND/OR DISECONOMIES OF SCALE?
}

\section{Dietrich Earnhart Lubomír Lízal}
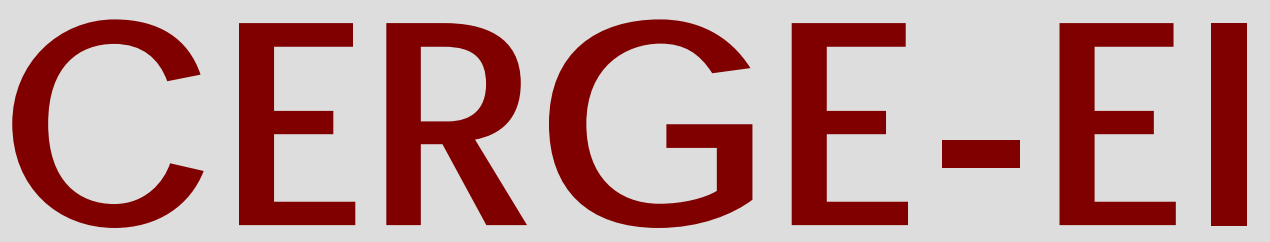

Charles University Centerfor Ec onomic Research and Graduate Education Academy of Sciences of the Czech Republic Ec onomic s Institute 


\title{
Working Paper Series 405 (ISSN 1211-3298)
}

\section{Pollution Control in a Transition Economy: \\ Do Firms Face Economies and/or Diseconomies of Scale?}

\author{
Dietrich Earnhart
}

Lubomír Lízal

CERGE-EI

Prague, February 2010 
ISBN 978-80-7343-208-9 (Univerzita Karlova. Centrum pro ekonomický výzkum a doktorské studium)

ISBN 978-80-7344-197-5 (Národohospodářský ústav AV ČR, v.v.i.) 


\title{
Pollution Control in a Transition Economy: Do Firms Face Economies and/or Diseconomies of Scale? ${ }^{1}$
}

\author{
Dietrich Earnhart and Lubomír Lízal \\ Earnhart@ku.edu_Lubomir.Lizal@cerge-ei.cz \\ University of Kansas CERGE-EI*
}

\begin{abstract}
We empirically assess whether firms face economies and/or diseconomies of scale with respect to air pollution control by evaluating the effects of production on firmlevel air emission levels using a panel of Czech firms during the country's transitional period of 1993 to 1998. By estimating a separate set of production-related coefficients for each individual sector, the analysis permits economies/diseconomies of scale to differ across sectors. More important, the analysis allows these scale effects to vary over time, which seems critical in the context of a transition economy, as the Czech government was tightening air protection polices by imposing more stringent emission limits and escalating emission charge rates. To assess whether these tighter policies expanded economies of scale, the analysis controls for heterogeneity across individual firms by examining intrafirm variation in emissions and production.
\end{abstract}

\begin{abstract}
Abstrakt
Empiricky posuzujeme, zda mají firmy výnosy z rozsahu ve výrobě vzhledem k emisím a odhadujeme vztah mezi výrobou a emisemi s využitím panelových dat českých podniků z let 1993 až 1998. Odhadnutím separátních regresních koeficientů pro každé odvětví analýza umožňuje porovnat výnosy z rozsahu mezi sektory. Výnosy z rozsahu se též mohou měnit v čase, což je důležitá dimenze $\mathrm{v}$ transformačních ekonomikách, kdy docházelo ke zpřísnění emisních limitů a nárůstu poplatků za znečištění. Abychom posoudili, zda přísnější emisní limity měly vliv na výnosy z rozsahu, bereme explicite do úvahy heterogenitu firem pomocí vnitropodnikové varice $\mathrm{v}$ emisích a ve výrobě.
\end{abstract}

Keywords: Czech Republic, environmental protection, pollution, production, economies of scale

JEL codes: D21, D62, Q53

\footnotetext{
${ }^{1}$ We acknowledge the financial support of a COBASE grant from the National Research Council.

Dietrich Earnhart acknowledges the financial support of the College of Liberal Arts and Sciences at the University of Kansas in the form of General Research Fund grant \# 2301467. He also thanks Mark Leonard for his research assistance.

*CERGE-EI is a joint workplace of the Center for Economic Research and Graduate Education, Charles University, and the Economics Institute of Academy of Sciences of the Czech Republic.

Address: CERGE-EI, P.O. Box 882, Politických vězňů 7, Prague 1, 111 21, Czech Republic
} 


\section{Introduction}

Several recent economic studies empirically examine the factors driving corporate environmental performance, generally measured by pollutant emissions, in mature market economies (Foulon et al., 2002; Konar and Cohen, 2001; Khanna and Damon, 1999) and transition economies (Wang and Wheeler, 2005; Bluffstone, 1999). While some of these studies include production as a control variable in their empirical analysis (Foulon et al., 2002; Khanna and Damon, 1999; Magat and Viscusi, 1990), they fail to scrutinize the important relationship between pollution and production and whether this relationship varies over time, which seems very important for a transition economy. ${ }^{2}$

In stark contrast to previous studies, our study closely examines the pollutionproduction relationship by analyzing firm-level environmental performance, as measured by air pollutant emissions, in the transition economy of the Czech Republic during the years 1993 to 1998. In particular, our study assesses whether Czech firms faced economies and/or diseconomies of scale with respect to pollution control by evaluating the effects of production on air pollutant emissions. Economies of scale exist when increased production prompts a decrease in the marginal amount of pollution per production unit (i.e., emissions are rising at a lesser rate than production); diseconomies of scale exist when the opposite occurs. By estimating a higher-order polynomial functional relationship between pollution and production, the analysis allows both economies and diseconomies of scale to exist depending on the level of production. By estimating a separate set of production-related coefficients for each individual sector, the analysis permits economies/diseconomies of scale to differ across sectors. More important, the analysis allows these scale effects to vary over time.

As with several countries in Central and Eastern Europe, the context of the Czech

2 Dasgupta et al. (2002) use the number of facility-level employees to divide Mexican air polluting facilities into three size categories and then assess whether emission intensities, as measured by tons of particulate matter per employee, differs across the size categories, while controlling for industry. 
transition economy is highly interesting for an assessment of pollution control. The Czech Republic had a substantially degraded environment in the 1990s, in particular, poor ambient air quality and high air pollution levels (World Bank, 1992). In addition, the Czech government needed to reduce industrial air pollutant emissions in order to qualify for membership in the European Union (EU). In response to public concern and later in anticipation of EU accession, between 1991 and 1998, the country's government was tightening air protection policies. In particular, it was requiring new stationary emission sources to meet stringent emission limits based on the installation of state-of-the-art treatment technologies and forcing existing stationary emission sources initially to meet "currently attainable" emission limits and eventually to meet new source limits (by the end of 1998), all while steadily increasing emission charge rates on all stationary emission sources. Consistent with the escalating protection policies, investment in environmental protection as a percent of gross domestic product (GDP) rose dramatically after 1991 and declined substantially after 1998, returning to pre-transition levels by 2000 . In keeping with this increased investment, throughout this same period, aggregate air pollutant emissions declined dramatically. ${ }^{3}$

Our exploration of production scale effects in this transition context helps to assess the effectiveness of the tighter air protection policies at prompting improvements in the relationship between production and emissions. If economies of scale expand in either scope or intensity (or diseconomies of scale shrink) as policies tightened, then these new protection policies would seem more effective than otherwise. ${ }^{4}$

Our results indicate that, in general, as production rises, the average Czech firm

3 Since the Czech experience with poor ambient air quality, initially high air pollutant emission levels, tightened air protection laws, substantial emission reductions, and pending entry into the EU are similar to other countries in Central and Eastern Europe, our study of the Czech Republic may be representative of other countries in the region during its transition period towards EU accession.

${ }^{4}$ One previous study - Earnhart and Lizal (2006b) - assesses the relationship between pollution and production. However, this previous study does not examine whether this relationship varies over time or across sectors, control for heterogeneity across individual firms, or assess policy effectiveness. 
enjoys economies of scale. However, in at least one year, the average Czech firm faces a mixture of economies and diseconomies of scale depending on the production level. In one exceptional year - 1998 - the average Czech firm encountered no appreciable relationship between emissions and production, indicating the average firm's amount of pollution appears relatively fixed, with no substantial link to variation in production. (The exception of 1998 may not be surprising since Czech GDP dropped $0.8 \%$ in 1998 after a smaller decline in the preceding year 1997.) From one perspective, this last result complicates our ability to assess scale effects. From another perspective, this result may reveal that increases in production do not lead to additional emissions, implying a great degree of pollution control when protection polices were most stringent in the sample period. These initial results stem from an estimation that does not distinguish production effects by sector. Sector-specific results indicate that the production scale effects differ dramatically across sectors. Specifically, both the metals sector and the energy sector enjoy economies of scale at lower production levels, while facing diseconomies of scale at higher production levels. In contrast, the chemicals sector encounters neither economies nor diseconomies of scale with an apparent proportional relationship between emissions and production. As important, the sector-specific results reveal that tighter protection policies had either a mixed or negligible effect on the emission-production relationship.

The next section develops a simple framework for understanding production scale effects. Section 3 describes the database on firm-level air pollutant emissions and production. Section 4 estimates and interprets the effects of production scale on air pollutant emissions. The final section concludes.

\section{Scale of Production: Economies and/or Diseconomies of Scale}

\subsection{General Framework}

The analysis assesses whether firms face economies and/or diseconomies of scale with respect to pollution control by constructing the level of pollution, denoted $p$, as a 
polynomial function of production, denoted $y$ :

First-Degree Polynomial: $\quad p=\alpha+\beta y$

Second-Degree Polynomial: $p=\alpha+\beta y+\gamma y^{2}$, and

Third-Degree Polynomial: $\quad \mathrm{p}=\alpha+\beta \mathrm{y}+\gamma \mathrm{y}^{2}+\delta \mathrm{y}^{3}$,

where $\alpha$ denotes a constant term. While equation (1a) does not permit assessment of whether a firm faces economies or diseconomies of scale, this equation permits assessment of the overall relationship between production and emissions based on a linear approximation. We consider this approximation only as a first step in our analysis and as an alternative specification if both equations (1b) and (1c) appear inappropriate, i.e., neither the quadratic nor cubic term proves significant.

Equation (1b) permits an assessment of whether a firm faces economies or diseconomies of scale but does not permit this assessment to depend on the level of production. The second derivative with respect to production, denoted $\mathrm{p}^{\prime \prime}$, equals $2 \gamma$. A firm faces economies of scale if $\mathrm{p}^{\prime \prime}<0$ and faces diseconomies of scale if $\mathrm{p}^{\prime \prime}>0$. If the quadratic parameter is negative $(\gamma<0)$, then a firm faces economies of scale regardless of the production level, as shown by Figure 1.c. If the quadratic parameter is positive $(\gamma>0)$, then a firm faces economies of scale regardless of the production level, as shown by Figure 1.d.

[Figure 1 here]

In contrast, equation (1c) permits an assessment of scale economies that depends on the level of production. The second derivative with respect to production is $\mathrm{p}^{\prime \prime}=2 \gamma+$

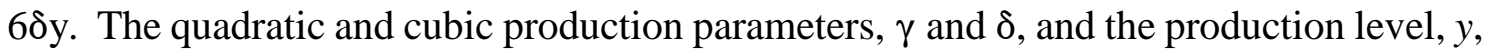
collectively determine whether a firm faces economies or diseconomies of scale. If the quadratic parameter is negative $(\gamma<0)$ but the cubic parameter is positive $(\delta>0)$, the sign of $\mathrm{p}^{\prime \prime}$ and thus the production scale effect depends on the level of production. Figure 1.a demonstrates that as production increases, a firm first faces economies of scale then later diseconomies of scale as $\mathrm{p}^{\prime \prime}$ shifts from negative to positive once production becomes 
sufficiently high for the cubic term to dominate. If the quadratic parameter is positive $(\gamma$ $>0)$ but the cubic parameter is negative $(\delta<0)$, the sign of $\mathrm{p}^{\prime \prime}$ and the production scale effect again depends on the level of production. Figure 1.b demonstrates that as production increases, a firm first faces diseconomies of scale then later economies of scale. If both the quadratic and cubic production parameters are negative $(\gamma<0, \delta<0)$, then $\mathrm{p}^{\prime \prime}$ is unambiguously negative and a firm faces economies of scale regardless of the production level, as shown in Figure 1.c. If both parameters are positive $(\gamma>0, \delta>0)$, then $\mathrm{p}^{\prime \prime}$ is unambiguously positive and a firm faces diseconomies of scale regardless of the production level, as shown in Figure 1.d.

Figure 1 displays a variety of emission-production relationships. The main text describes the primary relationships shown in Figure 1. Figures 1.c and 1.d also display four remaining possibilities that are relevant when either the quadratic or the cubic parameter equals zero $(\gamma=0$ or $\delta=0)$, which applies when either the estimated quadratic or cubic parameter is insignificantly different from zero. If the cubic term equals zero, then the third-degree polynomial becomes identical to the second-degree polynomial. Thus, the quadratic parameter $(\gamma)$ alone dictates whether a firm faces economies or diseconomies of scale; consequently, the identified scale effect is independent of the production level. Figure 1.c displays the case of economies of scale $(\gamma<0, \delta=0)$, and Figure 1.d displays the case of diseconomies of scale $(\gamma>0, \delta=0)$. If the quadratic term equals zero, then the cubic parameter $(\delta)$ alone dictates whether a firm faces economies or diseconomies of scale, and the identified scale effect is independent of the production level. Figure 1.c displays the case of economies of scale $(\gamma=0, \delta<0)$; Figure 1.d displays the case of diseconomies of scale $(\gamma=0, \delta>0)$.

This basic framework cleanly displays the possibilities of scale economies and scale diseconomies but does not explain the reasons for their existence. Given our empirical focus, we do not construct a formal theoretical model but instead draw upon the vast literature that examines returns to scale involving the standard relationship between output 
and inputs. This literature identifies two main forces: (1) an increased scale permits a greater division of labor and a specialization of function, and (2) an increased scale entails some loss in efficiency because managerial oversight may become more complex (Nicholson, 1992). While not exhaustive, this short list facilitates our empirical objective.

For conceptual insight, we draw upon the vast literature that examines returns to scale in the standard context: identifying the relationship between output and inputs. The relationship examined here is analogous to this standard relationship as long as we interpret pollution as the "output" of a "bad" (rather than a "good") and "production of the good" as the input into the generation of the "bad." The analogy between output of a "good" and output of a "bad" is obvious. The analogy between any standard input and "production of the good" is straightforward if one views "production" as a "composite input," i.e., production reflects the outcome of combining multiple inputs.

Given this pair of analogies, we draw upon the related theoretical literature, starting with Adam Smith's seminal research on returns to scale and followed by classical theoretical studies, such as Douglas (1948), Stigler (1951), and Ferguson (1969). These theoretical studies identify two main forces affecting returns to scale. First, an increased scale permits a greater division of labor and a specialization of function (Nicholson, 1992). Second, an increased scale entails some loss in efficiency because managerial oversight may become more complex (Nicholson, 1992). Put differently, the difficulties of managing a large-scale operation, especially maintaining good communication between managers and other workers, may eventually lead to decreases in the productivity of both labor and capital; for example, e.g., poor communication makes the workplace more impersonal, thus lowering morale (Pindyck and Rubinfeld, 1989). Other forces affect returns to scale. As a positive force, a larger scale of operation may generate increasing returns to scale by allowing firms to exploit more sophisticated, large-scale factories and equipment; as a negative force, a larger scale of operation may limit the entrepreneurial abilities of individual managers and other workers (Pindyck and Rubinfeld, 1989). 
Consistent with these described forces, the standard depiction of returns to scale reveals economies of scale at lower levels of production, where the positive forces of division of labor and specialization dominate, yet this depiction reveals diseconomies of scale at higher levels of production, where the ever increasing difficulties of managing an unwieldy operation dominate. This standard depiction is reflected in Figure 1.a. Since pollution represents a "bad" rather than a "good," the curvature of Figure 1.a is a mirror image of the curvature from the standard depiction. However, this standard depiction may not hold in all cases. For example, some firms may never face any meaningful managerial difficulties that are associated with larger scales of operation, at least within any relevant range, so economies of scale may exist at all relevant production levels, as shown in Figure 1.c. Lastly, neither economies nor diseconomies of scale may exist. According to Pindyck and Rubinfeld (1989, p. 185), if no inputs are unique and all inputs are fully available as the scale of operation increases, “...then constant returns to scale are guaranteed."

With proper interpretation, this insight on returns to scale for the standard relationship between output and inputs also applies to the relationship between pollution and production. First, the division of labor and specialization certainly applies to pollution control; as the scale of operations increases, employees are able to specialize in pollution control in general and eventually air pollution control in particular. Second, only larger firms may be able to justify the exploitation of more sophisticated, large-scale pollution abatement technologies. Third, a larger scale of operation may undermine managers' abilities to communicate pollution control directives to workers. Fourth, larger firms may limit the scope of entrepreneurial approaches to pollution control.

\subsection{Transition Economy of The Czech Republic}

We utilize this basic framework to examine the effects of production scale on firmlevel air pollutant emissions using data on Czech firms between 1993 and 1998, which is an ideal time period for our study. First, the Czech Republic had a substantially degraded 
environment, especially poor ambient air quality, after the collapse of communism (World Bank, 1992). In response to public concern, Czech government authorities took substantial and effective steps to decrease air emissions dramatically during the period 1991 to 1998 (Czech Ministry of Environment, 1998). Specifically, the Czech government raised the emission charge rates imposed on the four air pollutants examined in this study and lowered the permissible emission limits imposed on sources of the same air pollutants. Figure 2 displays the downward trend of economy-wide air emissions over this period. A substantial decline in economic activity in the early 1990s helps to explain part of this trend. In addition, firms' pollution control efforts, such as the installation of electrostatic precipitators ("scrubbers") and fuel switching, may also explain much of the displayed reduction in air pollution (World Bank, 1999).

[Figure 2 here]

Second, consistent with this focus on pollution control efforts, investment in environmental protection was most important during the period between 1992 and 1998, as shown in Figure 3. As a percentage of Czech gross domestic product (GDP), investment rose dramatically after 1991 from a level of $1.3 \%$ to a peak of $2.5 \%$ in 1997 and tailed off after 1998 back to a pre-transition level of $1.1 \%$ by 2000 .

[Figure 3 here]

Third, the Czech Republic was attempting to enter the EU during this period and was required to reduce its industrial emissions to qualify for membership.

These aspects of the Czech transition period prompt us to examine the possible effects of tighter air protection policies on the relationship between production and pollution. The tightening of Czech air protection policies most likely prompted Czech firms to lower their air pollutant emissions to some extent by investing in cleaner production technologies, better abatement technologies, and/or environmental management systems. These investments may have influenced the relationship between production and pollution. In particular, one would hope that these investments expanded the range or 
intensity of scale economies. Based on our basic framework, we pose this empirical question: As air protection policies tightened and polluting facilities were prompted to reduce their air pollutant emissions, were facilities more greatly exploiting the division of labor and specialization and/or mitigating the efficiency loss of complex oversight so that scale economies expanded in scope or intensity?

When answering this question, we do not attempt to identify the sources of any scale effects, e.g., complex management. In particular, we do not assess the various factors affecting a facility's pollution level that are influenced by the level of production. Production presumably indirectly affects the pollution level by influencing a facility's decisions concerning its production technology $[\mathrm{G}(\mathrm{y})]$, input quality $[\mathrm{Q}(\mathrm{y})]$, and abatement effort $[\mathrm{A}(\mathrm{y})]$. We could construct a more comprehensive pollution function that explicitly incorporates these additional explanatory factors: $\mathrm{p}=\mathrm{f}[\mathrm{y}, \mathrm{G}(\mathrm{y}), \mathrm{Q}(\mathrm{y}), \mathrm{A}(\mathrm{y})]$. Instead, we choose to telescope this more general relationship into the basic relationship: $p=f(y)$. With this telescoping in mind, the presence of economies (or diseconomies) of scale in pollution control may actually stem from economies (or diseconomies) of scale with respect to production technology, input quality, and/or abatement effort. We do not attempt to identify the channels connecting these elements and pollution as our data do not allow it. Indeed, this identification is not necessary for our objective as we explore a highly reduced form of emissions.

Given this perspective, we purposively exclude key explanatory factors, such as abatement effort. Thus, we are clearly not concerned about omitted variable bias. Rather than claiming that our analysis isolates the effect of production independent of other influences, we are claiming that the effect of production reflects all of the noted influences.

Consistent with our simplification regarding the emission-production relationship, we also simplify the analysis connecting air protection policies to the emission-production relationship. Rather than examining the specific policies, we simply allow the emissionproduction relationship to vary over time as the protection policies tighten. 
We do not analyze direct links relating tighter air protection policies to the emission-production relationship for two reasons. First, any conceptual analysis is complicated by the multiple dimensions that we funnel through the scale of operation as captured by the production level. In particular, the link between production and pollution stems from choices made regarding the use of production technologies, abatement technologies, environmental management systems, etc., and the noted policies most likely affected all of these choices, yet we only analyze the outcome of these many choices. Thus, we do not attempt to derive formally policy-related hypotheses. ${ }^{5}$

Second, empirical testing of any hypotheses derived for specific policies would be difficult since tighter protection policies were applied simultaneously. On this point, we acknowledge that our analysis may not be able to irrefutably isolate the effect of tighter air protection policies since other important elements were changing over this same time period. Nevertheless, we argue that protection policies are the primary element changing over the sample period with respect to the emission-production relationship.

Lastly, we argue that we are still able to assess scale economies and diseconomies in the presence of air protection policies because the methods used to impose emission charges and establish source-specific emission limits, in general, do not depend on production levels. Most obviously, emission charge rates do not depend on the level of production. As important, Czech environmental regulators established source-specific emissions limits based on either a concentration standard (e.g., milligrams of pollutant per liter of air) or a per production unit standard (e.g., tons of pollutant per ton of product) by scaling one of these standards according to the expected flow of air or production. Since neither standard depended on the production level in nearly all cases, the established

\footnotetext{
${ }^{5}$ Still, we could provide some indicative guidance when assessing possible effects of these policies. For example, escalating emission charge rates may have allowed smaller firms to justify the installation of more sophisticated abatement technologies. As another example, tighter effluent limits may have prompted firms to develop an environmental management system that helps track compliance yet involves large fixed costs, which can be better amortized across a larger operational scale. This illustrative list is neither complete nor definitive.
} 
source-specific limits reflected a proportional relationship between production and emissions.

\section{Data on Emissions and Production}

\subsection{Panel Data on Emissions and Production}

To examine production at Czech firms, we gather data from a database provided by the private data vendor Aspekt. From this database, we gather balance sheet and income statement data for the years 1993 to 1998, along with a firm's primary sectoral classification. The Aspekt database includes all firms traded on either the primary or secondary market and a majority of the remaining large Czech firms. This comprehensive database has been used by previous studies of Czech firm-level performance (Claessens and Djankov, 1999; Weiss and Nikitin, 2002; Hanousek et al., 2007; Djankov, 1999). Production is measured as production value in terms of Czech Crowns. To compare across the six years of the sample period, we adjust the production value using the Czech Consumer Price Index with 1998 as the base year. Our use of a fixed effects estimator (see Section 4.1) controls for any firm-specific variation in prices. As important, interactions with year indicators allow us to interpret production values as production quantity.

We also gather data on air pollutants emitted by Czech facilities during the years 1993 and 1998. The included pollutants are carbon monoxide (CO), sulfur dioxide $\left(\mathrm{SO}_{2}\right)$, particulate matter $(\mathrm{PM})$, and nitrous oxides $\left(\mathrm{NO}_{\mathrm{x}}\right)$, which represent the main and most heavily regulated pollutants in the Czech Republic, similar to other industrialized nations. The Czech Hydrometeorological Institute's REZZO-1 database includes emissions for large, stationary sources at the unit level. The Institute aggregates emissions to the level of each facility before publicly releasing the data. We further aggregate emissions across all facilities associated with a single firm. Thus, the analysis links firm-level emissions data with other firm-level data, consistent with previous studies of firm-level environmental performance (Konar and Cohen, 1997; Konar and Cohen, 2001; Earnhart and Lizal, 2006a; 
Khanna and Damon, 1999; Khanna et al., 1998; Arora and Cason, 1995; Arora and Cason, 1996). We add the four pollutants into one composite measure of air emissions, similar to previous studies of environmental performance (Konar and Cohen, 1997; Konar and Cohen, 2001; Earnhart and Lizal, 2006a; Khanna and Damon, 1999; Khanna et al., 1998; Arora and Cason, 1995; Arora and Cason, 1996). ${ }^{6}$

In order to generate the largest sample possible and to avoid a sample selection bias due to attrition, we create an unbalanced panel of firm-year observations for the time period 1993 to 1998 . After merging the production data set and the air emissions data set, we screen for meaningful data by applying the following criteria: non-missing emissions, positive production value, positive total assets, and positive fixed assets. This merger and screening generates an unbalanced panel of 2,632 observations from 631 firms.

\subsection{Descriptive Statistics}

Table 1 summarizes the data. Table 1.a summarizes emissions and production value. Table 1.b disaggregates the emissions data by year. Consistent with the economy-wide statistics shown in Figure 2, over the six years of the sample period, per-firm emissions declined. In 1993, the average firm emitted 1,287 tons of pollutants. Between 1993 and 1998, the mean value steadily and monotonically declined. By 1998, the average value had dropped to 774 tons. The average firm's emission intensity - emissions divided by production - also steadily and monotonically declined over this period from a level of 0.70 to 0.42 . These differences indicate that allowing the functional relationship between emissions and production to vary over time is warranted. Table 1.d displays the distribution of firms by industrial classification and demonstrates that per-firm emissions and emission intensity differ dramatically across the variety of sectors. These differences seem to indicate that controlling for sectoral variation is important. Table 1.c distinguishes per-firm

\footnotetext{
${ }^{6}$ Preliminary analysis indicates that use of an alternative measure of emissions - an emission chargeweighted sum of air pollutant levels - generates reasonably similar estimation results.
} 
emissions and emission intensity by both year and sector, with a focus on key sectors. Certain sectors display a dramatic decline in emission intensity over time, such as the transport equipment manufacturing sector, while other sectors display little variation in emission intensity over time, such as the non-metallic mineral products manufacturing sector. These differences seem to indicate that any consideration of time variation in the emission-production relationship should be sensitive to sectoral distinction.

[Table 1 here]

\section{Econometric Analysis of Air Pollutant Emission Levels}

\subsection{Econometric Structure}

In the econometric models, the dependent variable, $p_{\text {it }}$ denotes the amount of pollution emitted by firm $i$ in time period $t$. Emissions most likely depend strongly on the level of production, denoted $y_{\mathrm{it}}$. Production enters in three terms: linear $\left(y_{\mathrm{it}}\right)$, quadratic $\left(y_{\mathrm{it}}{ }^{2}\right)$, and cubic $\left(y_{\mathrm{it}}{ }^{3}\right)$. To control for variation over time, we include an indicator for each year between 1994 and 1998, with 1993 as the benchmark, collectively denoted as vector $T_{\mathrm{t}}$. To control for sector-specific variation, we generate an indicator for each sector displayed in Table 1.d, collectively denoted as vector $X_{i}$. Without additional manipulation, the fixed effects estimator, which is described below, subsumes the effects of sectoral indicators into its firm-specific fixed effects because the sector does not vary over time for a specific firm. For this reason, in the first stage of analysis, we ignore the sectoral indicators. In the second stage, we fully incorporate these sectoral indicators to the extent possible within the fixed effects estimator.

Given this notation, we formulate the following three polynomial (in production) econometric specifications:

$$
\begin{array}{ll}
1^{\text {st }} \text {-Degree: } & \mathrm{p}_{\mathrm{it}}=\alpha_{\mathrm{i}}+\beta \mathrm{y}_{\mathrm{it}}+\kappa \mathrm{T}_{\mathrm{t}}{ }^{\prime}+\mathrm{e}_{\mathrm{it}}, \\
2^{\text {nd }} \text {-Degree: } & \mathrm{p}_{\mathrm{it}}=\alpha_{\mathrm{i}}+\beta \mathrm{y}_{\mathrm{it}}+\gamma \mathrm{y}_{\mathrm{it}}{ }^{2}+\kappa \mathrm{T}_{\mathrm{t}}{ }^{\prime}+\mathrm{e}_{\mathrm{it}}, \\
3^{\text {rd }} \text {-Degree: } & \mathrm{p}_{\mathrm{it}}=\alpha_{\mathrm{i}}+\beta \mathrm{y}_{\mathrm{it}}+\gamma \mathrm{y}_{\mathrm{it}}{ }^{2}+\delta \mathrm{y}_{\mathrm{it}}{ }^{3}+\kappa \mathrm{T}_{\mathrm{t}}{ }^{\prime}+\mathrm{e}_{\mathrm{it}},
\end{array}
$$


where $\alpha_{\mathrm{i}}$ denotes the firm-specific intercept and $e_{\mathrm{it}}$ denotes the error term.

Production may be endogenous with respect to pollution. We address this concern in three ways. First, we use Granger causality tests to demonstrate that production appears to Granger-cause emissions, yet emissions do not appear to Granger-cause production, i.e., the Granger causality test statistics reject the null hypothesis of zero influence in the former case but cannot safely reject the null hypothesis of zero influence in the latter case.

When testing for Granger causality, we consistently use two lags of the variable whose causality is being assessed while varying the number of lags - one or two - in the control variable. Regardless of the specification of the time lag for the control variable, we find that emissions never Granger-cause production. The p-values for these Granger test statistics are above 0.95 , strongly indicating the lack of any relationship. Moreover, the pvalues for the individual coefficients are nearly as high; they are above 0.80 . On the other hand, production can Granger-cause emissions. The individual lag coefficients on production are significant for both specifications; they are even close to the $5 \%$ significance level for the one-lag specification, with p-values of 0.051 and 0.053 . The p-values for the joint tests indicate significance levels that are quite close to the $10 \%$ critical threshold; the p-value equals 0.102 and 0.149 for the one-lag specification and two-lag specification, respectively.

We employ a fixed effects estimator to generate these Granger causality test statistics. Consequently, we must address the fact that the presence of lagged values of the dependent variable on the right-hand side of the equations used to test the Granger causality in a dynamic panel data framework can lead to inconsistent parameter estimates unless the time dimension of the panel is very large (Nerlove, 1967; Nickell, 1981; Keane and Runkle, 1992). Anderson and Hsiao (1981) propose using twice-lagged levels of the right-hand side variables as instruments. Kiviet (1995) establishes the superiority of using twice-lagged levels over lagged differences and suggests an alternative approach that involves direct calculation of biases and correction of the least squares estimates. Simulation results in 
Judson and Owen (1999) show that Anderson-Hsiao estimators, while the least biased among the available alternatives, are considerably less efficient than the alternative proposed by Kiviet (1995). Fortunately, simulation results by Judson and Owen (1999, p. 13) also show that the bias problems are almost entirely concentrated in the coefficient of the lagged dependent variables, while biases in the coefficients of independent variables, which are the variables important for the test, are "relatively small and cannot be used to distinguish between estimators [including OLS]." In sum, we elect to ignore the bias corrections in the Granger-causality tests for the following reasons. First, we are not interested in point estimates of the noted coefficients. Second, any correction for biases would result in a significant loss of efficiency that would damage our ability to assess the causal relationships. Third, the coefficient bias is most likely small. Fourth, the unbalanced panel nature of the data greatly complicates the bias correction provided by Kiviet (1995).

Thus, with some confidence, while acknowledging that we possess only a very short time span for testing, we can eliminate any concern about a simultaneous determination of production and pollution and focus our concern on the endogeneity of production. ${ }^{7}$ Second, previous studies of environmental performance also incorporate a contemporaneous measure of production as an explanatory factor, implicitly treating production as predetermined with respect to pollution (Mickwitz, 2003; Foulon et al., 2002; Bluffstone, 1999; Khanna and Damon, 1999; Magat and Viscusi, 1990). Third and most important, we implement the Hausman test for exogeneity (Wooldridge, 2002). The Hausman test statistic fails to reject the null hypothesis of exogeneity in each specification. ${ }^{8}$

7 The test statistics and associated conclusions are consistent with the nature of pollution as a byproduct of production.

8 The test statistics are $1.01,0.22$, and 0.25 , respectively, for equations ( $2 a),(2 b)$, and (2c); $p$-values are $0.32,0.83$, and 0.80 . To generate these Hausman test statistics, we use several instruments for production: linear, quadratic, and cubic terms for preceding stock levels, equity, total assets, short-term and long-term liabilities, and short-term and long-term bank loans, along with the fixed to total assets ratio, depreciation to fixed assets ratio, and intangible to tangible fixed assets ratio. The failure to reject the null hypothesis of 
To accommodate the panel data structure, we estimate equations (2a), (2b), and (2c) using a fixed effects estimator since it dominates the other standard panel estimators: pooled OLS and random effects. Results from a set of F-tests of fixed effects, which are reported in Table 2.a, indicate that pooled OLS suffers from omitted variable bias due to excluding firm-specific intercept terms. Results from a set of Hausman tests of random effects, which are shown in Table 2.a, indicate that the random effects estimates are inconsistent in all cases. In contrast, fixed effects estimates are consistent by design. The fixed effects estimator controls for heterogeneity across individual firms.

We allow the functional relationship between emissions and production to vary over time by interacting each of the three production terms $-y_{\mathrm{it}}, y_{\mathrm{it}}{ }^{2}$, and $y_{\mathrm{it}}{ }^{3}-$ with each of the five year-specific indicators $-T_{94}, T_{95}, T_{96}, T_{97}$, and $T_{98}$. Then we insert the interactive terms into equations (2a), (2b), and (2c). For example, after inserting the interactive terms into the third-degree polynomial, the regression equation becomes the following:

$$
\mathrm{p}_{\mathrm{it}}=\alpha_{\mathrm{i}}+\beta \mathrm{y}_{\mathrm{it}}+\gamma \mathrm{y}_{\mathrm{it}}{ }^{2}+\delta \mathrm{y}_{\mathrm{it}}{ }^{3}+\kappa \mathrm{T}_{\mathrm{t}}{ }^{\prime}+\Gamma\left[\mathrm{y}_{\mathrm{it}} \mathrm{T}_{\mathrm{t}}{ }^{\prime}\right]+\Theta\left[\mathrm{y}_{\mathrm{it}}{ }^{2} \mathrm{~T}_{\mathrm{t}}{ }^{\prime}\right]+\xi\left[\mathrm{y}_{\mathrm{it}}{ }^{3} \mathrm{~T}_{\mathrm{t}}{ }^{\prime}\right]+\mathrm{e}_{\mathrm{it}} .
$$

This standard fixed effects model indirectly estimates the coefficients associated with the vector of sectoral indicators, $X_{j}$, since each sector-specific coefficient equals the average value of the firm-specific intercept coefficients associated with a particular sector. Thus, the first step of analysis controls for sectoral variation by allowing the emissionsproduction curve to shift up or down.

As the second step, we extend this consideration of sectoral variation by modifying the fixed effects estimator. First, we interact the sectoral indicators with each of the three production terms. By utilizing the full set of sectoral indicators, the analysis generates a coefficient set for each sector. Fixed effects estimation of each sector-specific sub-sample separately generates coefficient magnitudes that are identical to those reported here; however, the chosen approach improves the efficiency of the estimates, i.e., lower standard 
errors (and considerably so). By incorporating the sectoral interactions, the relationship between emissions and production is more uniform across firms because they operate in the same sector, thus, possessing similar production and abatement technologies and utilizing comparable production and pollution management methods.

Second, the analysis interacts each of the sector-specific production terms with the set of year indicators. This approach allows the emission-production relationship to vary over time and across sectors; i.e., this approach permits technological change to alter the production scale effects and to impact various sectors to a different degree and at a different pace.

Third, the analysis interacts the sectoral indicators with the year indicators, which allows year-specific intercepts to vary across sectors. Given the construction of the fixed effects estimator, no general intercept term exists. Instead, the model includes only a set of firm-specific intercepts. Thus, the year-specific intercepts represent temporal adjustments to the firm-specific intercepts that apply to all firms uniformly. By interacting the year-specific intercepts with the sectoral indicators, the analysis allows the firm-specific intercepts to adjust over time in a manner consistent with the sector of the specific firm. With proper interpretation, this accommodation implies that changes in the regulatory climate may alter the connections between firm-specific, time-invariant features and air pollution control in a manner consistent with the relevant sector rather than all sectors in general.

Based on the estimation results involving the metals sector, independent of the emission-production relationship, emissions fell over time, in general, as shown by the year-specific intercepts, with 1995 as the exception. Relative to 1993, emissions are significantly lower in 1997 and 1998 ( $\mathrm{p}=0.018,0.005$ ). The decline between 1996 and 1997 is also significant $(\mathrm{p}=0.013)$. This overall decline seems to indicate that by the end of the transition period Czech firms in the metals sector had lowered their pollution in ways not related to production scale effects. Based on the estimation results involving the energy 
sector, independent of the emission-production relationship, as shown by year-specific intercepts, emissions are comparable to their 1993 level with the exception of 1997, which is significantly lower $(\mathrm{p}=0.01)$. Nevertheless, these same intercepts indicate significant year-to-year differences - up, down, up - between the years 1995 to 1998 ( $\mathrm{p}=0.10,0.0002$, 0.005). These differences indicate that the energy firms' control of air pollution in ways not related to production scale effects does not appear sensitive to the progression of the Czech transition.

After generating these interaction terms, we insert them into equations (2a), (2b), and $(2 \mathrm{c})$. For example, after inserting the interaction terms into the first-degree polynomial, the regression equation becomes the following:

$$
\mathrm{p}_{\mathrm{it}}=\alpha_{\mathrm{i}}+\beta\left[\mathrm{y}_{\mathrm{it}} \mathrm{X}_{\mathrm{j}}{ }^{\prime}\right]+\kappa\left[\mathrm{T}_{\mathrm{t}}{ }^{\prime} \mathrm{X}_{\mathrm{j}}{ }^{\prime}\right]+\Gamma\left[\mathrm{y}_{\mathrm{it}} \mathrm{T}_{\mathrm{t}} \mathrm{X}_{\mathrm{j}}{ }^{\prime}\right]+\mathrm{e}_{\mathrm{it}} .
$$

This second analytical approach generates estimation results for each separate sector. A full evaluation and assessment of the results for all 19 sectors shown in Table 1.d seems unwarranted. Instead, we focus on a smaller subset of five important sectors:

(1) Manufacturing of Food Products, Beverages, and Tobacco ("foods");

(2) Manufacturing of Chemicals, Chemical Products, and Synthetic Fibers ("chemicals");

(3) Manufacturing of Basic Metals and Fabricated Metal Products ("metals");

(4) Manufacturing of Transport Equipment; and

(5) Energy: Electricity and Natural Gas (“energy").

Three sectors represent heavy polluters since they rank as the three largest Czech sectors in terms of air pollution. The energy sector contributes an amazing $42 \%$ of all sample-wide emissions, the metals sector contributes $21 \%$, and the chemicals sector contributes $14 \%$ (see Table 1.d). Collectively, these three sectors contribute an astounding $77 \%$ of samplewide emissions. Similarly, the average firms in these three sectors emit air pollutants at levels far above the sample average of 962 tons per year. The average energy firm emits 6,677 tons - almost seven times the sample average; the average chemicals firm emits 
2,732 tons, almost three times the sample average. The average metals firm emits 1,703 tons. As important, these three sectors invested heavily into environmental protection efforts during the sample period (Czech Ministry of Environment, 1999). The energy sector alone represented almost 50\% of all air-related environmental investment during the 1994 to 1999 period (Brůha et al., 2005).

To complement these three heavy polluting sectors, we add two relatively light polluting sectors. The foods sector and the transport equipment sector contribute only $2 \%$ and $1 \%$ of sample-wide emissions, respectively, while their average firms emit only 150 and 152 tons per year, respectively, as shown in Table 1.d. In addition, the foods sector is large; it contains the most firms of any sector: $15 \%$ of the sample.

In contrast to the positive reasons for selecting the chosen five sectors, negative reasons exist for purposively choosing not to examine the other 14 sectors.

First, we purposefully avoid excessively light polluting sectors mostly because our analysis requires sufficient variation in the dependent variable. For example, the average construction firm emits only 42 tons, less than $5 \%$ of the sample average of 962 tons. In addition, these light polluting sectors appear too "clean" to warrant consideration, at least for the purposes of policy analysis.

Second, we avoid disparate sectors. Certain sectors are simply too disparate to generate any meaningful analysis of the particular group of firms; the manufacturing n.e.c. sector represents the most extreme example. Disparate sectors belie the claim that sectoral distinction helps the analysis to better capture the emission-production relationship given greater uniformity across the examined firms. (The last three sectors shown in Table 1.d arguably represent the most disparate sectors in our sample. Given the small sample sizes of these sectors, we combined these already disparate sectors into an even more disparate, but sufficiently large, set of firms for the purposes of estimation.) Consequently, we do not evaluate disparate sectors. Nevertheless, our initial analysis examined two moderately disparate sectors: the machinery and equipment n.e.c. manufacturing sector (hereafter 
"machinery and equipment sector") and the non-metallic minerals manufacturing sector (hereafter "non-metallic minerals sector"). We examined these two particular moderatelydisparate sectors because their large sample sizes permitted us to demonstrate with some confidence the otherwise assumed claim that sufficient disparity undermines the ability to connect emissions and production. We utilized both sectors for this one purpose in order to assess the robustness of the demonstration: the machinery and equipment sector is a relatively light polluter, with an average annual emission level of 166 tons per firm, while the non-metallic minerals sector is a relatively moderate polluter, with an average annual emission level of 542 tons. Consistent with our claim that the dimension of disparity is important for the analysis, our initial analysis demonstrates that we are not able to estimate a statistically significant relationship between emissions and production for either moderately disparate sector.

Third, we do not assess three particular sectors - (1) agriculture, hunting, forestry, fisheries; (2) mining and quarrying; and (3) manufacturing of coke and refined petroleum - due to their tiny sample sizes, which are shown in Table 1.d. The loss of the first sector need not undermine the policy relevance of our analysis since the average firm in this sector emits a relatively very small amount (16 tons, as opposed to the sample average of 962 tons) and contributes only $0.01 \%$ of all emissions in our sample, as shown in Table 1.d. The loss of the other two sectors at first may potentially undermine the study's policy relevance since the average firm in these two sectors emits very large amounts of pollutants, especially in the mining and quarrying sector. Fortunately, the small sample sizes for these two sectors also imply that policymakers are able to address the firms in these sectors on a case-by-case basis rather than relying on any study of sectors. The mining and quarrying sector and the coke and refined petroleum manufacturing sector contain only 8 and 3 firms, respectively. Rather than allowing these three sectors to undermine the efficiency gains from our regression approach, we delete the firms in these sectors from our sample. Regardless of our interest in the remaining sectors, the analysis retains all of the other 
sectors in some useful form since their sample sizes permit at least reasonable accommodation in the regression system.

Fourth, we do not evaluate certain sectors for a combination of reasons argued above. For example, we do not evaluate the manufacturing of wood, wood products, pulp, paper, paper products, and publishing and printing sector. This sector includes somewhat disparate sub-sectors, as evidenced by previous studies' focus on only pulp and paper manufacturing facilities (e.g., Nadeau, 1997). A sample size of 89 observations is sufficiently small to constrain our analytical ability to investigate variation in the production term effects over time without exhausting the degrees of freedom, especially in the third-degree polynomial specification.

We employ the two described analytical approaches to generate estimation results, which we examine in the subsequent sub-section.

\subsection{Estimation Results}

\subsubsection{Fixed Effects Estimates: Without Sectoral Distinctions}

First, we consider the standard fixed effects estimates with and without interactions between the production terms and the year indicators. Results from the specifications lacking these interactions are shown in Table 2.a. Results from the three polynomial specifications are both qualitatively and quantitatively very similar. Consequently, we interpret them as a whole. Based on the estimated year indicators, relative to 1993 , emissions are lower in every single subsequent year. Moreover, the difference grows monotonically over time. Just as important, emissions are significantly rising in production, as indicated by the linear production term. Based on the first-degree polynomial, each additional one million Czech Crown increase in production value leads to an increase of 0.12 tons of air pollution. By including the quadratic production term, the effect rises to 0.44 tons; by additionally including the cubic production term, the effect rises further to 0.51 . The quadratic production effect is significantly negative in both relevant 
polynomial specifications. The cubic production term does not significantly affect emissions. Collectively, these results indicate that emissions are generally rising in production but at a declining rate regardless of the production level.

[Table 2 here]

Next, consider the results from the specifications that contain interactions between year indicators and the production terms, as shown in Table 2.b. Rather than tabulating the production-related coefficient estimates for the base year of 1993 and the interactions involving the five-year indicators, we display the year-specific production-related coefficients, which represent a simple sum of the base-year coefficients and the relevant year interaction coefficients, e.g., "1994 linear production" coefficient = ["1993 linear production" coefficient $]+$ ["1994 indicator $\times$ linear production" coefficient]. (Reported p-values are consistent with the calculated sum of the two coefficient estimates.) We assess the estimation results of the three specifications as a whole.

First, we identify general tendencies. The results for the linear production coefficients in general do not differ across the three specifications. With the exception of 1998, the linear production effect is significantly positive for each year. The quadratic production terms in the second-degree polynomial specification are significantly negative in every year except 1998. The cubic production terms are negative in all but one year and significantly so in three years; in the exceptional year of 1997, the cubic term is significantly positive.

Second, we utilize the year-specific coefficients to generate year-specific conclusions. We focus on the highest-order specification with a significant corresponding term unless a lower-order term is questionable. For 1993, the cubic production term is not significant in the third-degree polynomial. For both 1994 and 1996, the cubic production term is significant but the quadratic production term is insignificantly positive in the thirddegree polynomial yet significantly negative in the second-degree polynomial. Based on this pattern, we conclude that the second-degree polynomial dominates the third-degree 
polynomial for 1993, 1994, and 1996. Thus, emissions are generally rising in production but at a declining rate regardless of the production level so that firms enjoy economies of scale regardless of the production level (see Figure 1.c).

For 1995, the best specification is not obvious. Estimates from the third-degree polynomial reveal that the quadratic production effect is significantly positive while the cubic production effect is significantly negative. However, they also indicate that the linear production effect is insignificantly positive $(\mathrm{p}=0.47)$. If we focus on the cubic term, we select the third-degree polynomial and generate this conclusion: as production rises in 1995, firms first face diseconomies of scale but later enjoy economies of scale (see Figure 1.b). However, if we focus on the linear term, we select the second-degree polynomial and generate a conclusion identical to those for 1993, 1994, and 1996. For consistency with the surrounding years, we select the second-degree polynomial.

The 1997 estimates (based on the third-degree polynomial) indicate that, as production rises, firms first enjoy economies of scale, while later facing diseconomies of scale (see Figure 1.a).

The 1998 estimates indicate that no significant relationship exists between production and emissions according to any dimension: linear, quadratic, or cubic.

In sum, results from the standard fixed effects estimation that includes yearproduction interactions indicate that the third-degree polynomial is either unwarranted or problematic for five of the six years. This higher-order polynomial appears warranted only for 1997. For the other years, except 1998, the second-degree polynomial results indicate that firms face economies of scale regardless of the production level; the same conclusion is based on the results from the specifications lacking year-production interactions. In 1998, firms faced no appreciable increase in emissions as production rose. Thus, the inclusion of year-production interactions helps us to better classify the years 1997 and 1998. 


\subsubsection{Fixed Effects Estimates: With Sectoral Distinctions}

As the second analytical approach, we assess the estimation results generated by econometric specifications that interact sectoral indicators with year-specific production terms and year indicators. Results for the selected sectors are shown in Table 3. Rather than reporting all of the polynomial specifications for all five sectors of interest, we report for each sector only the "best" specification, as based on the significance of the production terms (e.g., if the linear production term is significant in only the first-degree polynomial, yet the quadratic and cubic terms are insignificant in the higher-order polynomials, then the first-degree polynomial is "best").

[Table 3 here]

First, we assess the metals sector, for which the third-degree polynomial is "best." As shown in Table 3.a, in every year, the linear production term is significantly positive, the quadratic production term is significantly negative, and the cubic term is significantly positive. Thus, regardless of the point in the Czech economic transition, the metals sector enjoys economies of scale at lower production levels, while it faces diseconomies of scale at higher production levels.

Yet, the quantitative nature of this emission-production relationship is changing over time. In general, the relationship is getting steeper and more curved, with stronger economies of scale in the lower production levels but stronger diseconomies of scale in the upper production levels. (In all three dimensions, 1995 represents an exception to the overall progression.) The linear production effect rises over time. Relative to 1993, the effect is significantly greater in 1997 and $1998(\mathrm{p}=0.0001)$. Moreover, starting from 1995, the effect rises monotonically through 1998, (significantly between each pair of years $[\mathrm{p}=0.001,0.0001,0.072])$. In contrast, the quadratic production effect becomes more negative over time, indicating stronger economies of scale. Relative to 1993, the effect is significantly more negative in 1996, 1997, and 1998 ( $\mathrm{p}=0.0001)$. Moreover, starting from 1995, the effect drops monotonically through 1998 (significantly between each pair of years 
$[p=0.0001])$. Yet, the cubic production effect rises over time too, indicating stronger diseconomies of scale. Relative to the initial year of 1993, the effect is significantly greater in 1996, 1997, and $1998(\mathrm{p}=0.08,0.0001,0.0001)$. And starting from 1995, the effect rises monotonically through 1998 (significantly between each pair of years [p=0.0001]).

Second, we assess the energy sector, for which the third-degree polynomial is "best." As shown in Table 3.a, the linear production term is significantly positive in every year, though the p-values for 1996 and 1998 are highly marginal at levels of 0.14 and 0.13 , respectively. The quadratic production term is significantly negative and the cubic term is significantly positive in every year. Thus, regardless of the point in the Czech economic transition, the energy sector enjoys economies of scale at lower production levels, while facing diseconomies of scale at higher production levels, similar to the metals sectors.

Yet, the quantitative nature of this emission-production relationship is changing over time, as with the metals sector. In general, the relationship is more curved, with stronger economies of scale in the lower production levels but stronger diseconomies of scale in the upper production levels. In general, the linear production effect does not vary over time from its initial 1993 level, with an exceptionally stronger effect in 1997 $[p=0.0002]$. (Nevertheless, this effect significantly varies between the years 1995 to 1998 $[\mathrm{p}=0.10,0.0001,0.0001]$.) In contrast, the quadratic production effect becomes more negative over time, indicating stronger economies of scale. Relative to 1993 , the effect is significantly more negative in every other year $(\mathrm{p}=0.0001)$. Moreover, starting from 1993 , the effect drops monotonically through 1997, while leveling off in 1998. [Only the drops between 1993 and 1994 and between 1996 and 1997 prove significant ( $\mathrm{p}=0.0001)$.] Yet, the cubic production effect rises over time too, indicating stronger diseconomies of scale. Relative to 1993 , the effect is significantly greater in every other year $(\mathrm{p}=0.0001)$ and rises monotonically through 1998 (significantly between each pair of years [p=0.0001, 0.07, $0.06,0.0001,0.04])$.

Since the metals sector and energy sector possess a similar emission-production 
relationship, we compare them using F-tests of equal effects. For this comparison, we organize the differences in three ways: (\#1) we assess separately each dimension - linear, quadratic, cubic - jointly for all years, (\#2) we assess the dimensions jointly for each single year, and (\#3) we assess the individual dimensions separately for each year. When considering the year-specific effects jointly (\#1), the two sectors are clearly different in all three dimensions $(\mathrm{p}=0.0001)$. Similarly, when considering the production effects jointly $(\# 2)$, the two sectors are clearly different in every year $(\mathrm{p}=0.0001)$. Specifically, each of the production effects - linear, quadratic, and cubic - is stronger for the energy sector than the metals sector in every year (\#3); note that the quadratic production effect is "stronger" when it is more negative. All of these differences are significant except the linear production effect in 1996 and 1998. These two exceptions aside, in every year, the energy sector faces a steeper but more curved emission-production relationship.

Third, we assess the chemical sector, for which the first-degree polynomial is "best." (In the second-degree polynomial, only the linear production term proves significant. In the third-degree polynomial, none of the production terms prove significant.) As shown in Table 3.b, the linear production term significantly and positively affects emissions in every year between 1993 and 1997. However, in 1998, this effect significantly drops from its 1993 level $(\mathrm{p}=0.001)$ and becomes insignificantly different from zero. ${ }^{9}$ Otherwise, the linear production effect does not vary over time. These results indicate that the chemicals sector encounters neither economies nor diseconomies of scale with a mostly stable, proportional relationship between emissions and production. ${ }^{10}$

Fourth, we assess the foods sector and transport equipment sector, which both

9 While insignificant, the coefficient magnitude drops so much in 1998 that it becomes negative despite the removal of a single "influential" observation. When constraining the linear production effect to be equal over time, the estimated coefficient is significantly positive $(p=0.0001)$. Thus, the 1998 effect represents the exception, especially since it represents the only year of economic recession in the sample period.

\footnotetext{
10 The year-specific intercepts reveal a stable control of emissions in ways not related to production scale effects on the part of individual chemical firms.
} 
represent relatively "clean" sectors. Consistent with this depiction, results for both sectors strongly indicate that emissions are not a function of production in any dimension regardless of the polynomial specification. ${ }^{11}$ (Results for the first-degree polynomials are shown in Table 3.b.) For both sectors, this conclusion is fully robust to the restriction of the production terms being equal over time, which cannot be rejected based on F-tests.

\subsection{Interpretation of Estimation Results}

The standard fixed effects estimates support the following conclusions. As production rises, the average Czech firm enjoys economies of scale in general and for most of the specific years. Estimates indicate that firms in 1993, 1994, 1995, and 1996 enjoy economies of scale regardless of the production level. As an extension, the standard estimates indicate that firms in 1997 also enjoy economies of scale, but only initially; at sufficiently high production levels, firms face diseconomies of scale. The results for 1998, a more exceptional year, indicate no discernable connection between emissions and production. These results indicate that tighter air protection policies did not expand Czech firms' enjoyment of scale economies. On the contrary, these results in general reveal that tighter policies seem to restrict the scope of scale economies. Results for 1998 are difficult to interpret since they do not permit an assessment of scale effects. However, from another perspective, these results may reveal that when protection policies were most stringent, Czech firms were able to increase their production without any appreciable increase in emissions, implying that tighter policies were quite successful.

We next interpret the results when the analysis allows the emission-production relationship to vary across sectors, with a focus on the three largest air polluting Czech sectors: metals, energy, and chemicals. The sector-specific results support these

\footnotetext{
${ }^{11}$ Firms in these sectors may be generating emissions typically from combustion for heating. If true, the level of emissions depends on important factors, such as the degree of insulation in facility buildings, that need not be related to production levels.
} 
conclusions. First, the production scale effects differ dramatically across sectors. Second, both the metals sector and the energy sector enjoy economies of scale at lower production levels, while facing diseconomies of scale at higher production levels. In contrast, the chemicals sector encounters neither economies nor diseconomies of scale with an apparent proportional relationship between emissions and production. Third, depending on the sector, the emission-production relationship varies over time as air protection policies tightened. For both the metals and energy sectors, economies of scale at lower production levels intensified yet, diseconomies of scale at higher production levels also intensified. Thus, the effect of tighter policies is clearly mixed. In contrast, for the chemicals sector, the effect of tighter protection policies is negligible, as shown by the stable emissionproduction relationship over time. The remaining sectors are too difficult to assess since no meaningful emission-production relationship exists in any year.

\section{Additional Policy Implications}

This final section draws additional policy implications, conditional on the imposition of source-specific emission limits, from our empirical results. First, the metals sector and energy sector face economies (diseconomies) of scale at lower (higher) production levels. When imposing emission limits on these sectors, Czech policymakers should accommodate these scale effects, while taking due care to assess whether the particular firm is reaping benefits from or struggling against these scale effects, i.e., permit writers should strongly condition emission limits on the production level. Second, the chemicals sector encounters neither economies nor diseconomies of scale. When imposing emission limits on this sector, Czech policymakers should avoid the conventional wisdom that "bigger is better" since in this case "bigger" is simply "more of the same;" instead, policymakers should scale quantity limits proportionally based on production and sectoral guidelines measured in concentration terms. Third, the remaining sectors face the challenge of no meaningful connection between emissions and production, which represents a 
blessing or curse depending on the (approximately) fixed level of emissions. When imposing emission limits on these sectors, Czech policymakers need not condition limits on the production level to any meaningful degree. 


\section{REFERENCES}

Anderson, T. W. and Cheng Hsiao (1981), "Estimation of Dynamic Models with Error Components," Journal of the American Statistical Association, 76, pg. 598-606.

Arora, Seema and Timothy Cason (1995), “An Experiment in Voluntary Environmental Regulation: Participation in EPA's 33/50 Program,"J. of Environmental Econ. and Mgt., 28 (3), pg. 271-286.

Arora, Seema and Timothy Cason (1996), "Why Do Firms Volunteer to Exceed Environmental Regulations? Understanding Participation in EPA's 33/50 Program," Land Economics, 72 (4), pg. 413-432.

Bluffstone, Randy (1999), “Are the Costs of Pollution Abatement Lower in Central and Eastern Europe? Evidence from Lithuania," Environment and Development Econ., 44, pg. 449-470.

Brůha, Jan, Milan Ščasný, and Pavel Machálek (2005), "Decomposition Analysis of Air Pollution Reduction in the Czech Republic," Proceedings of International Conference on Environmental Accounting - Sustainable Development Indicators, Ústí nad Labem (Czech Rep): Jan Evangelista Purkyně Univ.

Claessens, Stijn and Simeon Djankov (1999), "Ownership Concentration and Corporate Performance in the Czech Republic," Journal of Comparative Economics, 27(3), pg. 498-513.

Czech Ministry of Environment (1998), Statistical Environmental Yearbook of the Czech Republic, Prague: Czech Ministry of the Environment.

Czech Ministry of Environment (1999), Czech Ministry of the Environment: 1999 State Environmental Policy, Prague: Czech Ministry of the Environment.

Dasgupta, Susmita, Robert Lucas, and David Wheeler (2002), "Plant Size, Industrial Air Pollution, and Local Incomes: Evidence from Mexico and Brazil," Environment and Development Economics, 7, pg. 365-381.

Djankov, Simeon (1999), "Ownership Structure and Enterprise Restructuring in Six Newly Independent States," Comparative Economic Studies, 41(1), pg. 75-95.

Douglas, P.H. (1948), “Are There Laws of Production?” American Economic Review, 38, pg. 1-41. Earnhart, Dietrich and Lubomir Lizal (2006a), "Effects of Ownership and Financial Performance 
on Corporate Environmental Performance," Journal of Comparative Economics, 34(1), pg. 111-129.

Earnhart, Dietrich and Lubomir Lizal (2006b), "Pollution, Production, and Sectoral Differences," Comparative Economic Studies, 48, pg. 662-681.

Ferguson, C.E. (1969), The Neoclassical Theory of Production and Distribution, NY: Cambridge Univ Press.

Foulon, Jérôme, Paul Lanoie, and Benoît Laplante (2002), "Incentives for Pollution Control: Regulation or Information,” Journal of Environmental Economics and Mgt., 44, pg. 169187.

Hanousek, Jan, Evzen Kočenda, and Jan Svejnar, "Origin and Concentration: Corporate Ownership, Control, and Performance in Firms after Privatization," Economics of Transition, 15 (1), pg. 1-31.

Judson, Ruth, and Ann Owen (1999), "Estimating Dynamic Panel Data Models: A Guide for Macroeconomists," Economic Letters, 65, pg. 9-15.

Keane, Michael, and David Runkle (1992), "On the Estimation of Panel-Data Models with Serial Correlation When Instruments Are Not Strictly Exogenous," J. of Business and Economic Statistics, 10, pg. 1-9.

Khanna, Madhu, Wilma Rose Quimio, and Dora Bojilova (1998), “Toxics Release Information:

A Policy Tool for Environmental Protection," J. of Environmental Economics and Mgt., 36, pg. 243-266.

Khanna, Madhu and Lisa Damon (1999), "EPA's Voluntary 33/50 Program: Impact on Toxic Releases and Economic Performance of Firms," J. of Environmental Economics and Management, 37, pg. 1-25.

Kiviet, Jan F. (1995), “On Bias, Inconsistency, and Efficiency of Various Estimators in Dynamic Panel Data Models," Journal of Econometrics, 68, pg. 53-78.

Konar, Shameek and Mark Cohen (1997), "Information as Regulation: The Effect of Community Right to Know Laws on Toxic Emissions," J. of Environmental Economics and Mgt., 32, pg. 109-124.

Konar, Shameek and Mark Cohen (2001), "Does the Market Value Environmental Performance?" 
Review of Economics and Statistics, 83(2), pg. 281-289.

Magat, Wesley and Kip Viscusi (1990), "Effectiveness of the EPA's Regulatory Enforcement: The Case of Industrial Effluent Standards," Journal of Law and Economics, 33, pg. 331-360. Mickwitz, Per (2003), "Is It As Bad As It Sounds or As Good As It Looks? Experiences of Finnish Water Discharge Limits,” Ecological Economics, 45(2) (June), pg. 237-54.

Nerlove, Marc (1967), "Experimental Evidence on the Estimation of Dynamic Economic Relations in a Time Series of Cross-Sections," Economic Studies Quarterly, 18, pg. 42-74.

Nicholson, Walter(1992), Microeconomic Theory: Basic Principles and Extensions, Fifth Edition, Fort Worth (TX): Dryden Press.

Nickell, Stephen (1981), "Biases in Dynamic Models with Fixed Effects," Econometrica, 49, pg. 1417-1426.

Pindyck, Robert and Daniel Rubinfeld (1989), Microeconomics, New York: Macmillan.

Stigler, G.J. (1951), “The Division of Labor is Limited by the Extent of the Market," Journal of Political Economy, 59 (June), pg. 185-193.

Suits, Daniel (1984), “Dummy Variables: Mechanics v. Interpretation,” Review of Economics and Statistics, 66 (1) [Feb], pg. 177-180.

Wang, Hua and David Wheeler (2005), "Financial Incentives and Endogenous Enforcement in China's Pollution Levy System," Journal of Environmental Economics and Management, 49, pg. 174-196.

Weiss, Andrew and Georgiy Nikitin (2002), "Effects of Ownership by Investment Funds on The Performance of Czech Firms," in A. Meyendorff \& A. Thakor, eds: Designing Financial Systems in Transition Economies: Strategies for Reforming Central and Eastern Europe, MIT Press, Cambridge, p. 187-214.

World Bank (1992), “Czech and Slovak Federal Republic Joint Environmental Study,” Report No. 9623-CS.

World Bank (1999), Country Economic Memorandum - Czech Republic, World Bank, Washington, DC. 
Table 1 - Descriptive Statistics

Table 1.a. Statistical Summary of Production Value and Emissions

\begin{tabular}{|l|r|r|r|r|}
\hline Variable & \multicolumn{1}{|c|}{ Mean } & \multicolumn{1}{c|}{ Std Dev } & \multicolumn{1}{c|}{ Minimum } & \multicolumn{1}{c|}{ Maximum } \\
\hline Production (000s CZK) $^{\mathrm{a}}$ & $1,618,320.3$ & $4,618,679.4$ & $1,869.4$ & $89,906,017.9$ \\
\hline Emissions (tons) & 962.1 & $4,059.9$ & 0.0 & $48,883.0$ \\
\hline $\mathrm{N}=2,632$ & \multicolumn{4}{|l}{} \\
\hline
\end{tabular}

${ }^{\text {a }}$ Production value is adjusted to 1998 real Czech Crowns (CZK) using the Czech CPI.

Table 1.b. Year Distribution of Data and Year-Specific Descriptive Statistics for Emissions

\begin{tabular}{|r|r|r|r|r|}
\hline Year & \# of Firms & \% of Sample & $\begin{array}{c}\text { Mean Emissions } \\
\text { (tons) }\end{array}$ & $\begin{array}{c}\text { Mean Emission Intensity } \\
\text { (tons/CZK) }\end{array}$ \\
\hline 1993 & 356 & 13.52 & 1,287 & 0.704 \\
\hline 1994 & 469 & 17.81 & 1,017 & 0.657 \\
\hline 1995 & 468 & 17.77 & 1,002 & 0.640 \\
\hline 1996 & 484 & 18.38 & 853 & 0.571 \\
\hline 1997 & 457 & 17.36 & 891 & 0.524 \\
\hline 1998 & 398 & 15.14 & 774 & 0.420 \\
\hline
\end{tabular}

Table 1.c. Mean Emissions and Emission Intensity by Individual Sector and Year

\begin{tabular}{|c|c|c|c|c|c|c|c|}
\hline Sector & Year & Emissions & Intensity & Sector & Year & Emissions & Intensity \\
\hline \multirow{6}{*}{$\begin{array}{l}\text { Food Products, } \\
\text { Beverage, } \\
\text { Tobacco }\end{array}$} & 1993 & 267.00 & 0.367 & \multirow{6}{*}{$\begin{array}{l}\text { Basic Metals, } \\
\text { Fabricated } \\
\text { Metal } \\
\text { Products }\end{array}$} & 1993 & $2,567.50$ & 0.349 \\
\hline & 1994 & 179.73 & 0.376 & & 1994 & $1,703.22$ & 0.327 \\
\hline & 1995 & 142.56 & 0.240 & & 1995 & $2,069.76$ & 0.265 \\
\hline & 1996 & 116.26 & 0.210 & & 1996 & $1,672.78$ & 0.236 \\
\hline & 1997 & 119.41 & 0.188 & & 1997 & $1,124.96$ & 0.243 \\
\hline & 1998 & 113.98 & 0.211 & & 1998 & $1,340.98$ & 0.132 \\
\hline \multirow{6}{*}{$\begin{array}{l}\text { Chemicals, } \\
\text { Chemical } \\
\text { Products, } \\
\text { Synthetic } \\
\text { Fibers }\end{array}$} & 1993 & $3,070.58$ & 0.985 & \multirow{6}{*}{$\begin{array}{l}\text { Transport } \\
\text { Equipment }\end{array}$} & 1993 & 402.52 & 0.713 \\
\hline & 1994 & $2,786.67$ & 1.008 & & 1994 & 251.33 & 0.176 \\
\hline & 1995 & $2,444.58$ & 0.450 & & 1995 & 83.85 & 0.119 \\
\hline & 1996 & $1,794.10$ & 0.502 & & 1996 & 62.03 & 0.114 \\
\hline & 1997 & $3,575.35$ & 0.476 & & 1997 & 54.97 & 0.439 \\
\hline & 1998 & $2,653.87$ & 0.399 & & 1998 & 18.26 & 0.050 \\
\hline \multirow{6}{*}{$\begin{array}{l}\text { Other Non- } \\
\text { Metallic } \\
\text { Mineral } \\
\text { Products }\end{array}$} & 1993 & 505.24 & 0.582 & \multirow{6}{*}{ Energy } & 1993 & $13,609.60$ & 5.739 \\
\hline & 1994 & 585.47 & 0.494 & & 1994 & $7,232.48$ & 5.584 \\
\hline & 1995 & 503.41 & 0.403 & & 1995 & $6,761.53$ & 5.705 \\
\hline & 1996 & 463.39 & 0.336 & & 1996 & $5,782.97$ & 4.590 \\
\hline & 1997 & 625.42 & 0.391 & & 1997 & $6,026.41$ & 4.579 \\
\hline & 1998 & 594.58 & 0.317 & & 1998 & $4,151.59$ & 3.465 \\
\hline
\end{tabular}


Table 1.d. Sector-Specific Statistics for Emissions and Emission Intensity

\begin{tabular}{|l|r|r|r|r|r|}
\hline \multicolumn{1}{|c|}{ Industry } & $\begin{array}{c}\text { \# of } \\
\text { Obs }\end{array}$ & $\begin{array}{c}\text { \% of } \\
\text { Obs }\end{array}$ & $\begin{array}{c}\text { Emission } \\
\text { Mean } \\
\text { (tons) }\end{array}$ & $\begin{array}{c}\text { Emission } \\
\text { Intensity } \\
\text { (tons/CZK) }\end{array}$ & $\begin{array}{c}\text { \% of } \\
\text { Sample } \\
\text { Emissions }\end{array}$ \\
\hline \hline Agriculture, Hunting, Forestry, Fisheries & 20 & 0.76 & 16.1 & 0.1202 & 0.01 \\
\hline Mining and Quarrying & 33 & 1.26 & $3,621.6$ & 0.6431 & 4.72 \\
\hline Manuf.: Food, Beverages, \& Tobacco & 397 & 15.11 & 150.2 & 0.1437 & 2.36 \\
\hline $\begin{array}{l}\text { Manuf.: Textiles, Textile Products, } \\
\text { Leather, and Leather Products }\end{array}$ & 216 & 8.22 & 265.5 & 0.3786 & 2.26 \\
\hline $\begin{array}{l}\text { Manuf.: Wood, Wood Products, Pulp, } \\
\text { Paper, Publishing \& Printing }\end{array}$ & 89 & 3.39 & $1,116.7$ & 0.7255 & 3.92 \\
\hline Manuf.: Coke and Refined Petroleum & 14 & 0.53 & $1,107.6$ & 0.1028 & 0.61 \\
\hline $\begin{array}{l}\text { Manuf.: Chemicals, Chemical Products, } \\
\text { and Synthetic Fibers }\end{array}$ & 126 & 4.79 & $2,732.2$ & 0.8245 & 13.59 \\
\hline Manuf.: Rubber and Plastic Products & 53 & 2.02 & 92.9 & 0.1069 & 0.19 \\
\hline Manuf.: Other Non-Metallic Minerals & 234 & 8.90 & 542.3 & 0.4949 & 5.08 \\
\hline $\begin{array}{l}\text { Manuf.: Basic Metals, Fabricated Metal } \\
\text { Products }\end{array}$ & 308 & 11.72 & $1,702.5$ & 0.6048 & 20.71 \\
\hline Manuf.: Machinery \& Equipment n.e.c. & 301 & 11.45 & 165.6 & 0.1828 & 1.97 \\
\hline Manuf.: Electrical and Optical Equipment & 117 & 4.45 & 83.5 & 0.1357 & 0.39 \\
\hline Manuf.: Transport Equipment & 193 & 7.34 & 151.5 & 0.0553 & 1.16 \\
\hline Manufacturing n.e.c. & 92 & 3.50 & 144.8 & .2737 & 0.53 \\
\hline Energy: Electricity \& Natural Gas & 160 & 6.09 & $6,677.0$ & 2.6348 & 42.19 \\
\hline Construction & 120 & 4.57 & 42.0 & 0.0227 & 0.20 \\
\hline $\begin{array}{l}\text { Wholesale and Retail Trade; Motor } \\
\text { Vehicle Repair; Hotels and Restaurants; } \\
\text { Transport, Postal Service, Storage, \& } \\
\text { Telecommunication }\end{array}$ & 50 & 1.91 & 17.8 & 0.0272 & 0.04 \\
\hline $\begin{array}{l}\text { Finance, Real Estate, Rentals, Business, } \\
\text { Research, Public Administration }\end{array}$ & 73 & 2.74 & 14.4 & 0.0281 & 0.04 \\
\hline $\begin{array}{l}\text { Education, Health, and Veterinary } \\
\text { Services; Other Public and Social Services }\end{array}$ & 33 & 1.26 & 27.1 & 0.1517 & 0.04 \\
\hline
\end{tabular}

${ }^{a}$ These disparate sectors are combined because individually they represent too small a portion of the sample to facilitate estimation. This sectoral category also includes 17 observations $(0.65 \%$ of sample) from the sector of "Other n.e.c.". 
Table 2

Fixed Effects Estimation of Air Pollutant Emissions: Without Sectoral Distinctions

Table 2.a. Exclusion of Interactions between Year Indicators and Production Terms

\begin{tabular}{|c|c|c|c|c|c|}
\hline RHS Variable & $\begin{array}{c}1^{\text {st }} \text {-Degree } \\
\text { Polynomial } \\
\end{array}$ & \multicolumn{2}{|c|}{$\begin{array}{l}2^{\text {nd }}-\text { Degree } \\
\text { Polynomial } \\
\end{array}$} & \multicolumn{2}{|c|}{$\begin{array}{l}3^{\text {rd }} \text {-Degree } \\
\text { Polynomial } \\
\end{array}$} \\
\hline Production $^{\text {a }}$ & $\begin{array}{r}0.123 \quad * * \\
(0.028)\end{array}$ & $\begin{array}{r}0.435 \\
(0.055)\end{array}$ & $\begin{array}{l}* * \\
*\end{array}$ & $\begin{array}{r}0.505 \\
(0.084)\end{array}$ & $* * *$ \\
\hline Production-squared $^{\text {a }}$ & N/A & $\begin{array}{l}-3.56 \mathrm{E}-6 \\
(0.54 \mathrm{E}-6)\end{array}$ & $\begin{array}{l}* * \\
*\end{array}$ & $\begin{array}{l}-6.44 \mathrm{E}-6 \\
(2.62 \mathrm{E}-6)\end{array}$ & $* * *$ \\
\hline Production-cubed ${ }^{\text {a }}$ & N/A & N/A & & $\begin{array}{r}2.28 \mathrm{E}-11 \\
(2.03 \mathrm{E}- \\
11)\end{array}$ & \\
\hline $1994^{b}$ & $\begin{array}{l}-265.66 * * * \\
(106.70)\end{array}$ & $\begin{array}{l}-218.62 \\
(105.80)\end{array}$ & $* *$ & $\begin{array}{l}-215.26 \\
(105.80)\end{array}$ & $* *$ \\
\hline $1995^{b}$ & $\begin{array}{l}-336.05 \\
(107.60)\end{array}$ & $\begin{array}{l}-285.37 \\
(106.70)\end{array}$ & $\begin{array}{l}* * \\
*\end{array}$ & $\begin{array}{l}-281.18 \\
(106.80)\end{array}$ & $* * *$ \\
\hline $1996^{b}$ & $\begin{array}{l}-463.53 \quad * * \\
(107.60)\end{array}$ & $\begin{array}{l}-378.86 \\
(107.30)\end{array}$ & $\begin{array}{l}* * \\
*\end{array}$ & $\begin{array}{l}-371.02 \\
(107.50)\end{array}$ & $* * *$ \\
\hline $1997^{b}$ & $\begin{array}{l}-585.91 \\
(109.10)\end{array}$ & $\begin{array}{l}-477.68 \\
(109.20)\end{array}$ & $\begin{array}{l}* * \\
*\end{array}$ & $\begin{array}{l}-469.17 \\
(109.50)\end{array}$ & $* * *$ \\
\hline $1998^{b}$ & $\begin{array}{l}-778.64 \quad * * \\
(113.60)\end{array}$ & $\begin{array}{l}-647.08 \\
(114.20)\end{array}$ & $\begin{array}{l}* * \\
*\end{array}$ & $\begin{array}{l}-634.64 \\
(114.70)\end{array}$ & $* * *$ \\
\hline Adjusted $\mathrm{R}^{2}$ & 0.908 & 0.911 & & 0.910 & \\
\hline $\begin{array}{l}\text { F-test of Individual } \\
\text { Effects } \\
\quad \text { [significance level] }\end{array}$ & $\begin{array}{c}29.79 \\
{[0.0000]}\end{array}$ & $\begin{array}{c}26.43 \\
{[0.0000]}\end{array}$ & & $\begin{array}{r}26.29 \\
{[0.000}\end{array}$ & \\
\hline $\begin{array}{l}\text { Hausman FE vs. RE }{ }^{c} \\
\text { [significance level] }\end{array}$ & $\begin{array}{c}27.63 \\
{[0.0003]}\end{array}$ & $\begin{array}{c}26.71 \\
{[0.0004]}\end{array}$ & & $\begin{array}{r}24.76 \\
{[0.001}\end{array}$ & \\
\hline $\begin{array}{l}\text { No. of Firms / No. of } \\
\text { Obs }\end{array}$ & $630 / 2,626$ & $630 / 2,62$ & & $630 / 2$ & \\
\hline
\end{tabular}

Standard errors are noted inside parentheses; p-values are noted inside square brackets.

$*, * *$, and $* * *$ indicate statistical significance at the $10 \%, 5 \%$, and $1 \%$ levels, respectively.

Each regression also includes 630 firm-specific indicators.

${ }^{a}$ Units for production are millions of Czech crowns; units for production-squared are trillions of Czech crowns; units for production-cubed are quintillions of Czech crowns.

${ }^{\mathrm{b}}$ Omitted category is 1993.

${ }^{c}$ Estimation of the random effects model includes 19 sector-specific indicators while restricting the sum of these indicators' coefficients to zero. 
Table 2.b. Inclusion of Interactions between Year Indicators and Production Terms:

\begin{tabular}{|c|c|c|c|c|c|c|c|}
\hline \multirow[t]{2}{*}{ Regressor } & \multirow[t]{2}{*}{ Year } & \multicolumn{2}{|c|}{$\begin{array}{c}1^{\text {st }} \text {-Degree } \\
\text { Polynomial }\end{array}$} & \multicolumn{2}{|c|}{$\begin{array}{l}2^{\text {nd }} \text {-Degree } \\
\text { Polynomial }\end{array}$} & \multicolumn{2}{|c|}{$\begin{array}{l}3^{\text {rd }} \text {-Degree } \\
\text { Polynomial }\end{array}$} \\
\hline & & Effect & $\mathrm{p}$-value & Effect & $\mathrm{p}$-value & Effect & $\mathrm{p}$-value \\
\hline \multirow{6}{*}{$\begin{array}{l}\text { Linear } \\
\text { Production } \\
\text { Terms }^{\text {a }}\end{array}$} & 1993 & 0.1914 & 0.0001 & 0.4584 & 0.0001 & 0.5423 & 0.0001 \\
\hline & 1994 & 0.1610 & 0.0001 & 0.4994 & 0.0001 & 0.3479 & 0.0074 \\
\hline & 1995 & 0.2102 & 0.0001 & 0.4860 & 0.0001 & 0.0832 & 0.4685 \\
\hline & 1996 & 0.1456 & 0.0001 & 0.3421 & 0.0001 & 0.2014 & 0.0825 \\
\hline & 1997 & 0.0522 & 0.0765 & 0.0314 & 0.6478 & 0.2266 & 0.0322 \\
\hline & 1998 & -0.0669 & 0.1598 & -0.0221 & 0.8168 & -0.0566 & 0.7092 \\
\hline \multirow{6}{*}{$\begin{array}{l}\text { Quadratic } \\
\text { Production } \\
\text { Terms }^{\text {a }}\end{array}$} & 1993 & N/A & N/A & -8.18 E-6 & 0.0001 & -8.55 E-6 & 0.0991 \\
\hline & 1994 & N/A & N/A & - 13.7 E-6 & 0.0001 & 13.37 E-6 & 0.1958 \\
\hline & 1995 & N/A & N/A & -10.5 E-6 & 0.0001 & 32.96 E-6 & 0.0001 \\
\hline & 1996 & N/A & N/A & -6.98 E-6 & 0.0001 & 6.56 E-6 & 0.3222 \\
\hline & 1997 & $\mathrm{~N} / \mathrm{A}$ & N/A & -1.23 E-6 & 0.0825 & - 11.97 E-6 & 0.0122 \\
\hline & 1998 & N/A & N/A & -3.60 E-6 & 0.2146 & 3.84 E-6 & 0.7897 \\
\hline \multirow{6}{*}{$\begin{array}{l}\text { Cubic } \\
\text { Production } \\
\text { Terms }^{\text {a }}\end{array}$} & 1993 & N/A & N/A & N/A & N/A & -0.08 E-9 & 0.2167 \\
\hline & 1994 & N/A & N/A & N/A & N/A & -0.73 E-9 & 0.0008 \\
\hline & 1995 & N/A & N/A & N/A & N/A & -0.85 E-9 & 0.0001 \\
\hline & 1996 & N/A & N/A & N/A & N/A & -0.26 E-9 & 0.0019 \\
\hline & 1997 & $\mathrm{~N} / \mathrm{A}$ & N/A & N/A & N/A & 0.07 E-9 & 0.0851 \\
\hline & 1998 & N/A & N/A & $\mathrm{N} / \mathrm{A}$ & N/A & -0.28 E-9 & 0.3768 \\
\hline \multirow{6}{*}{$\begin{array}{l}\text { Year- } \\
\text { Specific } \\
\text { Intercepts }\end{array}$} & 1993 & $\mathrm{~N} / \mathrm{A}$ & N/A & $\mathrm{N} / \mathrm{A}$ & N/A & N/A & N/A \\
\hline & 1994 & -172.24 & 0.1210 & -169.48 & 0.1779 & 40.09 & 0.7713 \\
\hline & 1995 & -317.94 & 0.0045 & -261.66 & 0.0372 & 155.70 & 0.2534 \\
\hline & 1996 & -342.03 & 0.0021 & -202.28 & 0.1050 & 29.14 & 0.8292 \\
\hline & 1997 & -313.53 & 0.0054 & 53.13 & 0.6742 & 16.36 & 0.9047 \\
\hline & 1998 & -371.41 & 0.0017 & -63.87 & 0.6349 & 71.36 & 0.6240 \\
\hline \multicolumn{2}{|l|}{ Adjusted $\mathrm{R}^{2}$} & \multicolumn{2}{|c|}{0.9142} & \multicolumn{2}{|c|}{0.9174} & \multicolumn{2}{|c|}{0.9208} \\
\hline \multicolumn{2}{|c|}{$\begin{array}{l}\text { F-test: Fixed Effects } \\
\text { [significance level] }\end{array}$} & \multicolumn{2}{|c|}{$\begin{array}{c}31.14 \\
{[0.0001]}\end{array}$} & \multicolumn{2}{|c|}{$\begin{array}{c}28.42 \\
{[0.0001]}\end{array}$} & \multicolumn{2}{|c|}{$\begin{array}{c}28.20 \\
{[0.0001]}\end{array}$} \\
\hline \multicolumn{2}{|c|}{$\mathrm{N}$ of Firms/N of Obs } & \multicolumn{2}{|c|}{$630 / 2,626$} & \multicolumn{2}{|c|}{$630 / 2,626$} & \multicolumn{2}{|c|}{$630 / 2,626$} \\
\hline
\end{tabular}

Year-Specific Production Terms equal Sum of Base-Year Effects and Year Interactive Terms.

Standard errors are noted inside parentheses; $p$-values are noted inside square brackets.

$*$, **, and *** indicate statistical significance at the $10 \%, 5 \%$, and $1 \%$ levels, respectively.

Each regression also includes an intercept term, in addition to 630 firm-specific indicators.

${ }^{a}$ Units for production are millions of Czech crowns; units for production-squared are trillions of

Czech crowns; units for production-cubed are quintillions of Czech crowns.

${ }^{\mathrm{b}}$ Omitted category is 1993. 
Table 3

Fixed Effects Estimation of Air Pollutant Emissions: With Sectoral Distinctions

Table 3.a. Metals Sector and Energy Sector

\begin{tabular}{|c|c|c|c|c|c|}
\hline \multirow{2}{*}{ Regressor } & \multirow{2}{*}{ Year } & \multicolumn{2}{|c|}{ Metals Sector $(\mathrm{N}=308)$} & \multicolumn{2}{|c|}{ Energy Sector $(\mathrm{N}=160)$} \\
\hline & & Coefficient & p-value & Coefficient & p-value \\
\hline \multirow{6}{*}{$\begin{array}{l}\text { Linear } \\
\text { Production } \\
\text { Terms }\end{array}$} & 1993 & 1.038 & 0.0034 & 4.58 & 0.0134 \\
\hline & 1994 & 1.099 & 0.0046 & 4.97 & 0.0148 \\
\hline & 1995 & 0.669 & 0.0579 & 5.05 & 0.0207 \\
\hline & 1996 & 1.273 & 0.0034 & 3.39 & 0.1446 \\
\hline & 1997 & 2.500 & 0.0001 & 9.74 & 0.0001 \\
\hline & 1998 & 2.855 & 0.0001 & 4.21 & 0.1301 \\
\hline \multirow{6}{*}{$\begin{array}{l}\text { Quadratic } \\
\text { Production } \\
\text { Terms }\end{array}$} & 1993 & $-0.2304 \mathrm{E}-3$ & 0.0001 & $-2.083 \mathrm{E}-3$ & 0.0006 \\
\hline & 1994 & $-0.2710 \mathrm{E}-3$ & 0.0001 & -4.022 & 0.0001 \\
\hline & 1995 & $-0.1678 \mathrm{E}-3$ & 0.0001 & -4.535 & 0.0001 \\
\hline & 1996 & -0.3483 E-3 & 0.0001 & -4.953 & 0.0001 \\
\hline & 1997 & $-0.6253 \mathrm{E}-3$ & 0.0001 & -9.036 & 0.0001 \\
\hline & 1998 & -0.7048 E-3 & 0.0001 & -8.851 & 0.0001 \\
\hline \multirow{6}{*}{$\begin{array}{l}\text { Cubic } \\
\text { Production } \\
\text { Terms }\end{array}$} & 1993 & 2.848 E-9 & 0.0001 & 120.83 E-9 & 0.0189 \\
\hline & 1994 & 3.343 E-9 & 0.0001 & 379.27 E-9 & 0.0001 \\
\hline & 1995 & 0.904 E-9 & 0.1737 & 464.28 E-9 & 0.0001 \\
\hline & 1996 & 4.327 E-9 & 0.0001 & 568.34 E-9 & 0.0001 \\
\hline & 1997 & 11.957 E-9 & 0.0001 & $1,108.1$ E-9 & 0.0001 \\
\hline & 1998 & 14.106 E-9 & 0.0001 & $1,282.1 \mathrm{E}-9$ & 0.0001 \\
\hline \multirow{5}{*}{$\begin{array}{l}\text { Year- } \\
\text { Specific } \\
\text { Intercepts }\end{array}$} & 1994 & -122.35 & 0.6989 & -553.91 & 0.4544 \\
\hline & 1995 & 84.10 & 0.7905 & -743.18 & 0.3054 \\
\hline & 1996 & -205.12 & 0.5204 & 15.16 & 0.9836 \\
\hline & 1997 & -755.30 & 0.0180 & $-1,933.21$ & 0.0120 \\
\hline & 1998 & -918.18 & 0.0051 & -352.67 & 0.6538 \\
\hline \multicolumn{2}{|c|}{ System Adjusted $\mathrm{R}^{2}$} & \multicolumn{4}{|l|}{0.9704} \\
\hline \multicolumn{2}{|c|}{$\begin{array}{l}\text { F-test: Fixed Effects } \\
\text { [significance level] }\end{array}$} & \multicolumn{4}{|l|}{$\begin{array}{l}16.83 \\
{[0.0001]}\end{array}$} \\
\hline \multicolumn{2}{|c|}{$\mathrm{N}$ of Firms/ $\mathrm{N}$ of Obs } & \multicolumn{4}{|l|}{$611 / 2,560$} \\
\hline
\end{tabular}

${ }^{a} 1993$ is the benchmark year. 
Table 3.b. Sectors: Chemicals; Foods, Beverages, \& Tobacco; Transport Equipment

\begin{tabular}{|c|c|c|c|c|c|c|c|}
\hline \multirow[t]{2}{*}{ Regressor } & \multirow[t]{2}{*}{ Year } & \multicolumn{2}{|c|}{$\begin{array}{c}\text { Chemicals Sector } \\
(\mathrm{N}=126)\end{array}$} & \multicolumn{2}{|c|}{$\begin{array}{c}\text { Foods, Beverages, \& } \\
\text { Tobacco Sector }(\mathrm{N}=397)\end{array}$} & \multicolumn{2}{|c|}{$\begin{array}{l}\text { Transport Equipment } \\
\text { Sector }(\mathrm{N}=193)\end{array}$} \\
\hline & & Coeff. & $\mathrm{p}$-value & Coeff. & p-value & Coeff. & $\mathrm{p}$-value \\
\hline \multirow{6}{*}{$\begin{array}{l}\text { Linear } \\
\text { Production } \\
\text { Terms }\end{array}$} & 1993 & 0.4675 & 0.0001 & 0.0302 & 0.9006 & 0.2120 & 0.2193 \\
\hline & 1994 & 0.4714 & 0.0001 & 0.0358 & 0.8812 & 0.2931 & 0.2574 \\
\hline & 1995 & 0.4357 & 0.0001 & 0.0482 & 0.8389 & 0.1762 & 0.4163 \\
\hline & 1996 & 0.3643 & 0.0410 & 0.0255 & 0.9159 & 0.1467 & 0.4145 \\
\hline & 1997 & 0.5225 & 0.0030 & 0.0347 & 0.8487 & 0.1021 & 0.4100 \\
\hline & 1998 & -0.1025 & 0.6011 & 0.0434 & 0.8465 & 0.1310 & 0.6259 \\
\hline \multirow{5}{*}{$\begin{array}{l}\text { Year- } \\
\text { Specific } \\
\text { Intercepts }{ }^{\text {a }}\end{array}$} & 1994 & 100.98 & 0.8381 & -73.74 & 0.7942 & -125.06 & 0.6911 \\
\hline & 1995 & -313.17 & 0.5310 & -130.68 & 0.6473 & -100.31 & 0.7551 \\
\hline & 1996 & -187.95 & 0.7299 & -129.70 & 0.6466 & -104.71 & 0.7434 \\
\hline & 1997 & -697.83 & 0.2026 & -152.44 & 0.6037 & -79.03 & 0.8113 \\
\hline & 1998 & 621.44 & 0.2609 & -181.09 & 0.5440 & -100.11 & 0.8013 \\
\hline \multicolumn{2}{|c|}{ System Adjusted R ${ }^{2}$} & \multicolumn{6}{|l|}{0.9704} \\
\hline \multicolumn{2}{|c|}{$\begin{array}{l}\text { F-test: Fixed Effects } \\
\text { [significance level] }\end{array}$} & \multicolumn{6}{|l|}{$\begin{array}{l}16.83 \\
{[0.0001]}\end{array}$} \\
\hline \multicolumn{2}{|c|}{$\mathrm{N}$ of Firms $/ \mathrm{N}$ of $\mathrm{Obs}$} & \multicolumn{6}{|c|}{$611 / 2,560$} \\
\hline
\end{tabular}

a 1993 is the benchmark year. 


\section{Figure 1}

Economies and Diseconomies of Scale

Figure 1.a: $\tau<0, \delta>0$

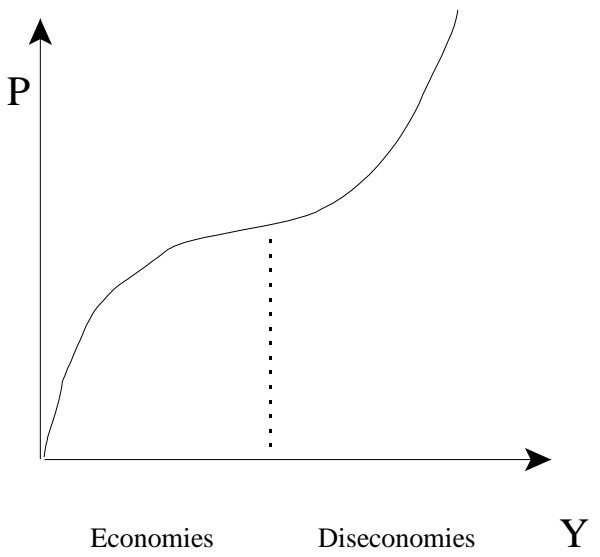

Figure 1.c: $\tau \leq 0, \delta \leq 0$

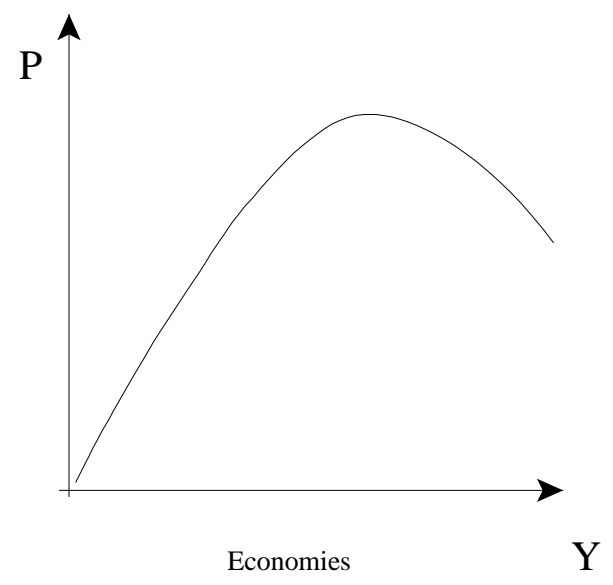

Figure 1.b: $\tau>0, \delta<0$

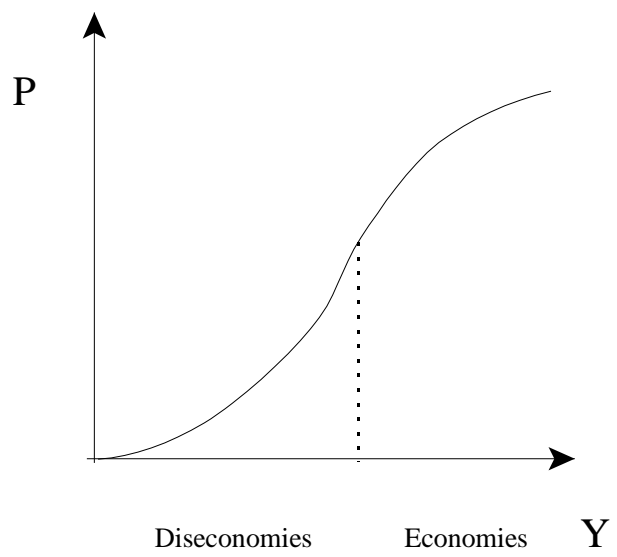

Figure 1.d: $\tau \geq 0, \delta \geq 0$

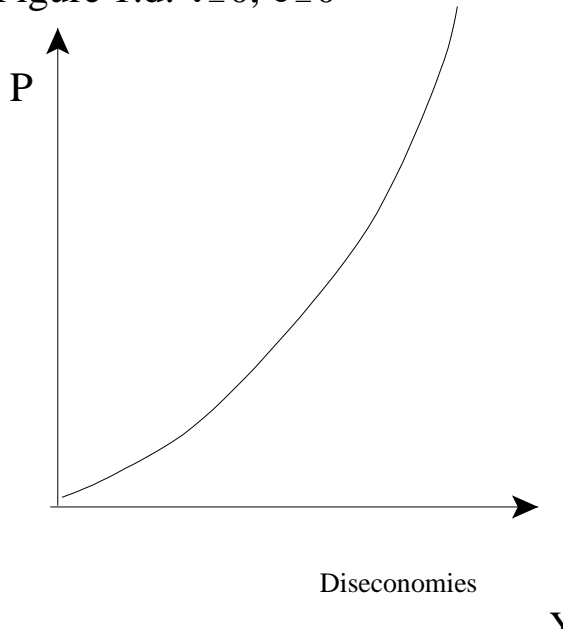


Figure 2: Air Pollutant Emissions in Czech Republic

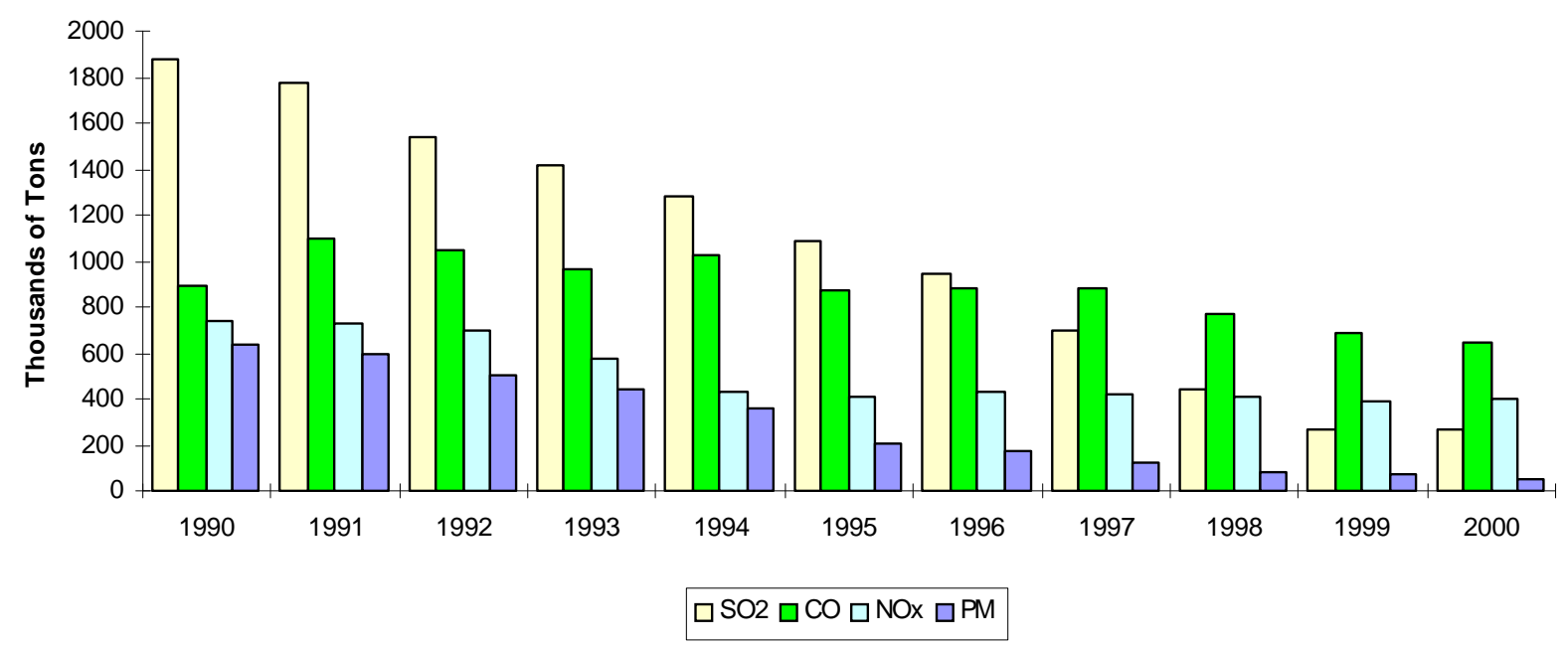


Figure 3: Investment in Environmental Protection

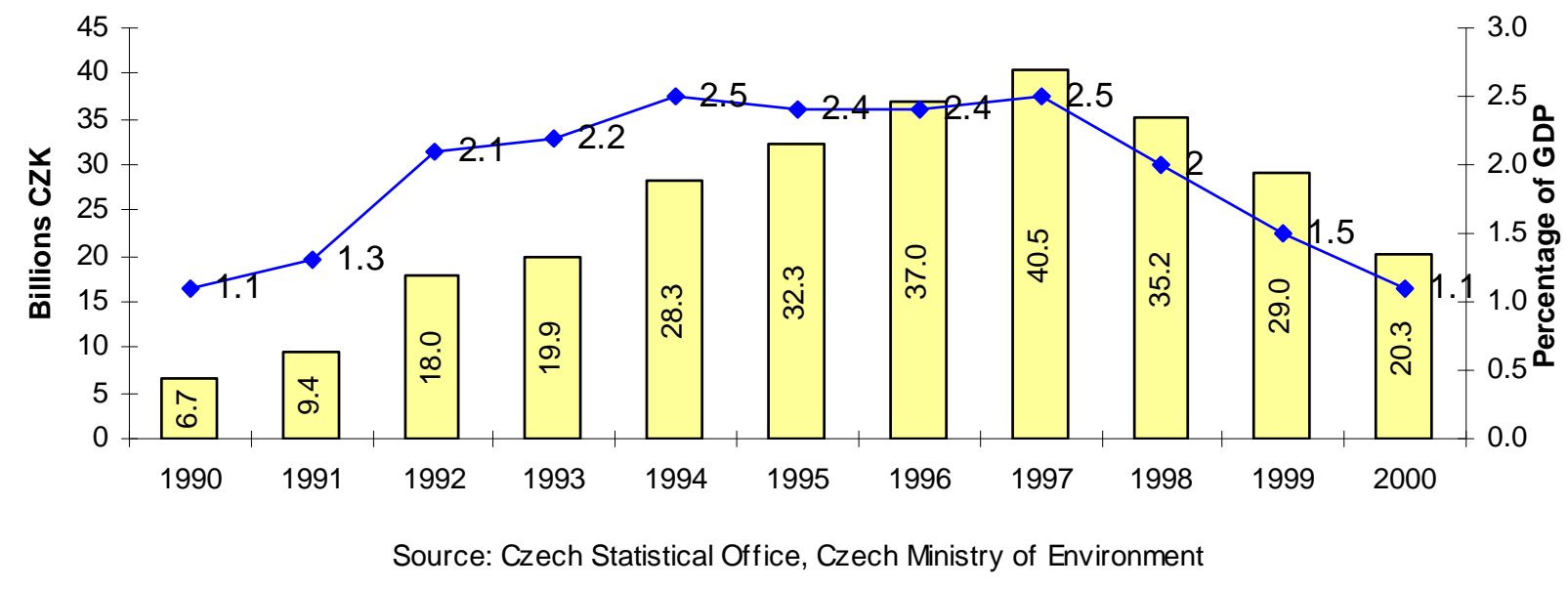


Individual researchers, as well as the on-line and printed versions of the CERGE-EI Working Papers (including their dissemination) were supported from the following institutional grants:

- Economic Aspects of EU and EMU Entry [Ekonomické aspekty vstupu do Evropské unie a Evropské měnové unie], No. AVOZ70850503, (2005-2010);

- Economic Impact of European Integration on the Czech Republic [Ekonomické dopady evropské integrace na ČR], No. MSM0021620846, (2005-2011);

Specific research support and/or other grants the researchers/publications benefited from are acknowledged at the beginning of the Paper.

(c) Dietrich Earnhart and Lubomír Lízal, 2010.

All rights reserved. No part of this publication may be reproduced, stored in a retrieval system or transmitted in any form or by any means, electronic, mechanical or photocopying, recording, or otherwise without the prior permission of the publisher.

Published by

Charles University in Prague, Center for Economic Research and Graduate Education (CERGE) and

Economics Institute ASCR, v. v. i. (EI)

CERGE-El, Politických vězňŭ 7, 11121 Prague 1, tel.: +420 224005 153, Czech Republic.

Printed by CERGE-EI, Prague

Subscription: CERGE-EI homepage: http://www.cerge-ei.cz

Editors: Directors of CERGE and EI

Managing editors: Deputy Directors for Research of CERGE and EI

ISSN 1211-3298

ISBN 978-80-7343-208-9 (Univerzita Karlova. Centrum pro ekonomický výzkum

a doktorské studium)

ISBN 978-80-7344-197-5 (Národohospodářský ústav AV ČR, v. v. i.) 
CERGE-EI

P.O.BOX 882

Politických vězňů 7

11121 Praha 1

Czech Republic http://www.cerge-ei.cz 